\title{
Anticancer gold(III) peptidomimetics: from synthesis to in vitro and ex vivo biological evaluation
}

\author{
Giulia Boscutti $^{[a, g]}$, Chiara Nardon ${ }^{[a, g]}$, Luciano Marchiò ${ }^{[b]}$, Marco Crisma ${ }^{[c]}$, Barbara Biondi ${ }^{[c]}$, Daniele \\ Dalzoppo $^{[\mathrm{d}]}$, Lisa Dalla Via ${ }^{[\mathrm{d}]}$, Fernando Formaggio ${ }^{[a, c]}$, Angela Casini ${ }^{[e, f]}$, Dolores Fregona*[a]
}

\begin{abstract}
Five new $\mathrm{Au}(\mathrm{III})$-peptidodithiocarbamato complexes of the type [Au'"'Br$r_{2}\left(\mathrm{dtc}_{\mathrm{A}}-\mathrm{AA}_{1}-\mathrm{AA}_{2}-\mathrm{OR}\right]\left(\mathrm{AA}_{1}=\mathrm{Sar}, \mathrm{L} / \mathrm{D}-\mathrm{Pro} ; \mathrm{AA}_{2}=\mathrm{L} / \mathrm{D}-\mathrm{Ala}\right.$, Aib; $\mathrm{R}=\mathrm{OtBu}, \mathrm{TEG}$ ), differing in the amino acidic sequence and/or the chiral amino acid configuration, were designed to enhance the tumor selectivity and bioavailability. The gold(III)-based moiety was functionalized to exploit the targeting properties of the peptidomimetic ligand towards two peptide transporters (namely, PEPT1 and PEPT2) up-regulated in several tumor cells. The compounds were synthesized and fully characterized, mainly by means of elemental analysis, one and two dimensional NMR spectroscopy, FT-IR and UV-Vis spectrophotometries. The crystal structures of three compounds were also solved by X-ray diffraction. In vitro cytotoxicity studies using a panel of human tumor cell lines (A549, MCF-7, A2780, H1975, H460 and A431) showed that the dtc-Pro-Aib-OtBu derivative is very effective, with $\mathrm{GI}_{50}$ values much lower than those of Cisplatin. It was thus selected for evaluating the stability under physiological conditions and possible interaction with serum albumin as well as for PARP-1 enzyme inhibition assays and preliminary ex vivo toxicity experiments on healthy rat tissues.
\end{abstract}

\section{Introduction}

Cisplatin, cis-diamminodichloridoplatinum(II), since the serendipitously discovery of its antiproliferative activity by Rosenberg in 1968, is still one of the most used metal-based drugs in anticancer therapy. ${ }^{[1]}$

[a] Dr. G. Boscutti, Dr. C. Nardon, Prof. F.Formaggio, Prof. D. Fregona Department of Chemical Sciences University of Padova

via Marzolo, 1. 35131 Padova (Italy)

E-mail: dolores.fregona@unipd.it

[b] Prof. L. Marchiò

SCVSA Department

University of Parma

Parco Area delle Scienze, 17/A. 43121 Parma (Italy)

[c] Dr. M. Crisma, Dr. B. Biondi, Prof. F.Formaggio

Institute of Biomolecular Chemistry, Padova Unit, CNR

via Marzolo 1, 35131 Padova (Italy).

[d] Prof. L. Dalla Via, Dr. D. Dalzoppo

Department of Pharmaceutical Sciences

University of Padova

via Marzolo, 5. 35131 Padova (Italy)

[e] Prof. A. Casini

School of Chemistry, Cardiff University, Main Building, Park Place, CF10 3AT Cardiff (United Kingdom)

[f] Groningen Research Institute of Pharmacy, University of Groningen,

A. Deusinglaan 1, 9713 GV Groningen, The Netherlands.

[g] These authors contributed equally.

Supporting information for this article is given via a link at the end of the document.
In spite of its significant antitumor activity, its use is generally limited by the poor selectivity toward malignant cells. Indeed, Cisplatin is toxic also to normal tissues, mainly causing nausea, anorexia, alopecia, and most of all nephro-, oto- and neurotoxicity. ${ }^{[2]}$ Moreover, the activation of resistance mechanisms, which can be either intrinsic or acquired after some cycles of therapy, ${ }^{[3-5]}$ make Cisplatin inactive against some tumor types, narrowing its spectrum of action. Despite these restrictions, it is still administered to patients to treat testicular cancer and, in combination with other chemotherapeutics, some ovarian, small cell lung, bladder and breast tumors. ${ }^{[6]}$

The poor chemotherapeutic index of this widely clinically-used drug gave rise to the development of second- and thirdgeneration platinum-based derivatives and opened the frontiers to the design of new anticancer drugs based on alternative metals. ${ }^{[7-9]}$ In particular, the research has focused on the synthesis of new complexes with better selectivity for cancerous cells and, consequently, with less side effects. ${ }^{[10]}$

In our research group, new "first generation" $\mathrm{Au}$ (III)dithiocarbamato compounds with general formula $\left[\mathrm{Au}^{\mathrm{III}} \mathrm{X}_{2}(\mathrm{dtc})\right]$ $(\mathrm{X}=\mathrm{Cl}, \mathrm{Br}$; dtc= various dithiocarbamates) were designed and prepared. Interestingly, these compounds showed outstanding antiproliferative activity both in vitro towards different human cancer cell lines and in vivo against murine tumors and human xenografts. ${ }^{[11]}$ Moreover, neither cross resiatance nor the main drawbacks of cisplatin-based therapy were detected.- Indeed, in the last years it was demonstrated that $\mathrm{Au}$ (III)-dithiocarbamato complexes exploit a mechanism of action different from that of the clinically-established platinum drugs. ${ }^{[11-12]}$ These promising results represented the starting point for the development of new "second generation" compounds, designed to improve the bioavailability, tumor selectivity and cellular uptake [13-15] compared to the previously synthesized compounds. New complexes of the type [Aul'I $\mathrm{X}_{2}$ (op-dtc)] $(\mathrm{X}=\mathrm{Cl}, \mathrm{Br}$; op-dtc= various oligopeptide dithiocarbamates) were prepared, of which oligopeptides could be recognized and up-taken by specific peptide transporters called PEPTs (PEPT1 and PEPT2). ${ }^{[16-17]}$ Such proton-coupled integral membrane proteins belong to the SLC (SoLute Carrier) family of transporters. They can cotransport $\mathrm{H}^{+}$ions and substrates across the cell membrane, creating an inward-directed proton gradient that provides the driving force for the accumulation of a substrate in the cell against its concentration gradient. ${ }^{[18]}$ They are predominantly present in epithelial cells of small intestine, mammary glands, lung, choroid plexus and kidney. A unique feature of these transporters is their capability for sequence-independent transport of most possible di- and tripeptides. ${ }^{[18-19]}$ In addition to their physiological substrates, PEPTs also mediate the membrane transport of many pharmacologically active peptidomimetic drugs and prodrugs, such as $\beta$-lactam antibiotics, angiotensin-converting-enzyme 
(ACE) inhibitors, renin inhibitors, thrombin inhibitors, or the anticancer drug bestatin, owing to their structural resemblance to di- and tri-peptides. ${ }^{\text {20-21] }}$

The rationale of our choice to functionalize the metal center with dipeptides relies on the possibility of increasing selectivity towards cancer cells and the cell uptake via recognition of the organic tail by PEPTs, being overexpressed in some human cancer types. ${ }^{[22-24]}$ To accomplish this strategy, we recently synthesized and characterized five novel complexes of general formula [Au'l'Br$\left.r_{2}\left(\mathrm{dtc}-\mathrm{AA}_{1}-\mathrm{AA}_{2}-\mathrm{OR}\right)\right]$ (Figure 1) where $\mathrm{AA}_{1}=\mathrm{Sar}$ (Sar= N-methylglycine), L/D-Pro; $A A_{2}=L / D-A l a, A i b \quad(A i b=\alpha-$ aminoisobutyric acid) and $\mathrm{R}=\mathrm{O}$ tBu, TEG (triethylene glycol methyl ether). One of them was selected as a model compound for evaluating the solution stability in different media and its possible interaction with serum albumin.

In this work, two elements of novelty appear with respect to the previously synthesized compounds:[13-14] (i) the replacement of Sar with Pro, the only coded amino acid having a secondary amine; (ii) the use of both $\mathrm{L}$ and D-configurated amino acids to analyze the role of the amino acid chirality, which might affect both transporter recognition and mechanism of action. All compounds were tested in vitro against a panel of human tumor cell lines. The biological evaluation of these new complexes was followed by preliminary evaluation of toxicity, carried out by their ex vivo incubation with healthy rat tissues using the so called "precisioncut tissue slices" technique. This technique is an FDA-approved model for drug toxicity and metabolism studies. ${ }^{[25-32]}$ With respect to the investigation of the mechanism of action, in the last years there is increasing interest about PARP (poly(ADP-ribose) polymerase) inhibitors as anticancer agents, including $\mathrm{Au}(\mathrm{III})$ compounds, ${ }^{[33-37]}$ since a cascade of apoptosis-promoting signals starts upon enzyme inactivation. These inhibitors can be either used alone or in combination with other well-established DNAdamaging drugs, thus amplifying their cytotoxic effect. ${ }^{[38-40]}$

Based on this scientific and clinical interest, this work also focused on the interaction of our compounds with PARP-1. Notably, the nuclear levels of PARP-1 in human breast cancer (especially in triple-negative tumors) have been directly correlated to the stage of progression of the malignant transformation, representing a parameter to predict poor prognosis. ${ }^{[41-45]}$

\section{Results and Discussion}

\section{Chemistry}

Synthesis. We synthesized the five novel gold(III) dipeptidocomplexes reported in Figure 1. The choices of the amino acid residues and ester type were made taking into account the previous results obtained for similar compounds, in which the dithiocarbamato moiety was functionalized with esterified oligopeptide chains, whose length ranged from 2 to 5 amino acids. ${ }^{[13-14]}$ In the complexes IT01, IT02 and IT05 (Figure 1) the $\mathrm{N}$ terminus amino acid is Sar whereas in IT03 and IT04 it is the N,Ndisubstituted amino acid proline (Pro). This replacement was made to investigate the effect of the rigidity on the antiproliferative activity of the final compounds.
The chosen $C$-terminus amino acids were selected to be Ala or Aib in light of the promising results collected for the Gly- and Aibcontaining compounds AuD6 and AuD8 ${ }^{[15]}$ In particular, Ala was selected because of its intermediate properties between Aib and Gly.

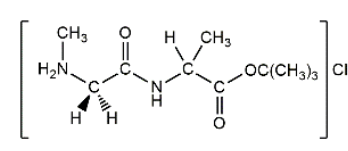

HCl'H-Sar-L/D-Ala-O(t-Bu) P1/P2

P1/P2<smiles>CCOC(=O)[C@](C)(NC(=O)[C@@H]1CCCN1)C(=O)Cl</smiles>

HClH-L/D-Pro-Aib-O( $t$-Bu)

P3/P4<smiles>CC(NC(=O)CN(C)C1=[SH][Y](Br)(Br)S1)C(=O)OC(C)(C)C</smiles>

[Au"'Br ${ }_{2}$ (dtc-Sar-L/D-Ala-O(t-Bu))] IT01/ IT02<smiles>CCOC(=O)OCC(C)(C)C</smiles>

[Au'"Br ${ }_{2}$ (dtc-L/D-Pro-Aib-O(t-Bu))] IT03/ IT04

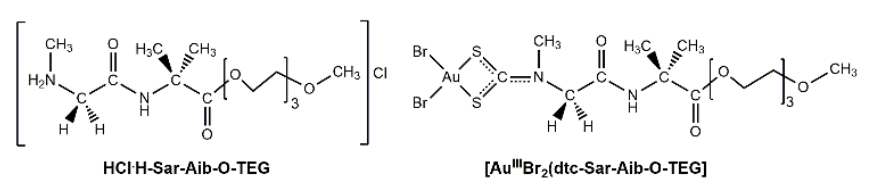
P5

Figure 1. Chemical structures of the dipeptides P1-P5 and the corresponding gold(III)-dithiocarbamato complexes (IT01-IT05).

Concerning the $C$-terminus of the dipeptides, the carboxyl function was esterified as we previously observed that a free $\mathrm{COOH}$ group is detrimental to stability and antiproliferative activity. A screening between -OMe, -OEt and -OtBu esters demonstrated that the higher the hydrophobic character and sterically-hindered nature of the ligands, the greater the biological activity of the final $\mathrm{Au}(\mathrm{III})$ complexes. ${ }^{[14]}$ Therefore, in this work the tert-butyl ester was chosen as a $C$-terminus group. On the other hand, a higher hydrophobicity lowers the solubility in aqueous media, a problem for the administration of the complexes in vivo. Thus, a TEGfunctionalized gold(III) complex was prepared to enhance the water solubility due to the presence of ethyloxy-groups (Figure 1), while maintaining the steric hindrance at the $C$-terminus of the complex. The synthesis of the hydrochloride esterified dipeptide derivatives $\mathrm{HCl} \cdot \mathrm{H}-\mathrm{Sar}-\mathrm{L} / \mathrm{D}-\mathrm{Ala}-\mathrm{O}$ tBu (P1 and P2, respectively), $\mathrm{HCl} \cdot \mathrm{H}-\mathrm{L} / \mathrm{D}-\mathrm{Pro}-\mathrm{Aib}-\mathrm{OtBu}$ (P3 and P4, respectively) and $\mathrm{HCl} \cdot \mathrm{H}-$ Sar-Aib-OTEG (P5) was performed using classic solution synthesis reagents and procedures, according to the Scheme S1. ${ }^{[46-49]}$

After liquid chromatography and crystallization purification, the dipeptides were deprotected at the $\mathrm{N}$-terminus by catalytic hydrogenation over $\mathrm{Pd} / \mathrm{C}$. The $\mathrm{Z}$ (benzyloxycarbonyl) $\mathrm{N}$ protecting group was used for its stability and clean removal by catalytic hydrogenolysis. After Z-removal, the dipeptides were turned into their more stable hydrochloride salts by treatment with $\mathrm{HCl}$ in diethylether solution. The hydrochloride dipeptides were then directly used for the synthesis of the corresponding gold(III) dithiocarbamato complexes: [Au'l'Br${ }_{2}$ (dtc-Sar-L/D-Ala-OtBu)] 
(IT01 and IT02, respectively), [Au'"'Br${ }_{2}$ (dtc-L/D-Pro-Aib-OtBu)] (IT03 and IT04, respectively) and [ $\mathrm{Au}^{\mathrm{II}} \mathrm{Br}_{2}$ (dtc-Sar-Aib-OTEG)] (IT05) (Scheme 1, Figure 1). Despite extensive efforts, we were not able to isolate the free dithiocarbamato ligand in a stable form. Thus, a one-pot approach was adopted for the synthesis of the complexes. The dithiocarbamato ligand was generated in situ, treating the water solution of the hydrocloride dipeptide with $\mathrm{NaOH}$ and 2 equivalents of $\mathrm{CS}_{2}$ in an ice bath. After the dithiocarbamato derivative formation, the ligand solution was immediately added to a water solution containing 0.5 eq. of $\mathrm{KAuBr}_{4}$, leading to the precipitation of yellow ochre-brown powdery solids. The complexes were washed with cold water and then purified through flash chromatography.

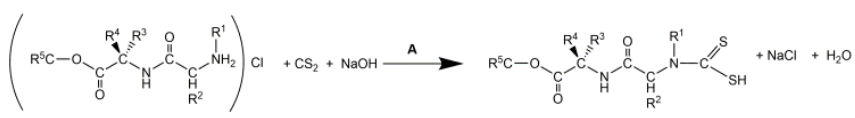

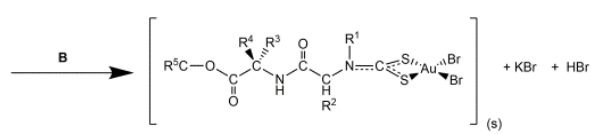

Scheme 1. General synthetic route for the synthesis of gold(III) dithiocarbamato complexes IT01-IT05. (IT01/02 $\mathrm{R}_{1}=\mathrm{CH}_{3} ; \mathrm{R}_{2}=\mathrm{H} ; \mathrm{R}_{3}=\mathrm{CH}_{3} ; \mathrm{R}_{4}=\mathrm{H} ; \mathrm{R}_{5}=-t \mathrm{Bu}$. IT03/04 $\mathrm{R}_{1}+\mathrm{R}_{2}=-\left(\mathrm{CH}_{2}\right)_{3}-; \mathrm{R}_{3}=\mathrm{R}_{4}=\mathrm{CH}_{3} ; \mathrm{R}_{5}=-\mathrm{tBu}$. IT05: $\mathrm{R}_{1}=\mathrm{CH}_{3} ; \mathrm{R}_{2}=\mathrm{H} ; \mathrm{R}_{3}=$ $\left.\mathrm{R}_{4}=\mathrm{CH}_{3} ; \mathrm{R}_{5}=-\mathrm{TEG}\right) . \mathrm{A}=\mathrm{H}_{2} \mathrm{O}, 0^{\circ} \mathrm{C} ; \mathrm{B}=\mathrm{KAuBr}_{4}, \mathrm{H}_{2} \mathrm{O}, 0^{\circ} \mathrm{C}$.

Characterization. The dipeptides (P1-P5) and the corresponding gold(III)-dithiocarbamato derivatives (IT01-IT05) were characterized by means of different techniques, which confirmed the obtainment of the designed structures.

The stoichiometry of the final compounds was checked through elemental analysis, while their thermal behavior was investigated by thermogravimetric (TG) and differential scanning calorimetric (DSC) analyses (Table S1). A good correlation was detected between experimental and calculated (to metallic gold) weight loss values for all the compounds.

Regarding the structural characterization, data collected by FT-IR spectrophotometry and mono and bidimensional NMR spectroscopy proved particularly useful to characterize the synthesized complexes (Table 1 and Tables S2-S3).

The discussion of the FT-IR analysis (Table S2) is reported in the Supporting Information ${ }^{[50-55]}$.

The synthesized dipeptides P1-P5 and the corresponding gold(III) complexes IT01-IT05 were further characterized by means of both mono $\left({ }^{1} \mathrm{H}\right.$, Table 1) and bidimensional $\left(\left[{ }^{1} \mathrm{H},{ }^{13} \mathrm{C}\right] \mathrm{HMBC}\right.$, Table S3) NMR analysis.

In general, all proton signals of the dipeptide backbone undergo a downfield shift upon complexation, less evident when the distance from the metal center increases (Table 1). The protons located in the -NCSS proximal groups display a chemical shift increase of about 0.5 to $1 \mathrm{ppm}$, while the amide signal follows an opposite trend, being upfield-shifted by 0.1-0.2 ppm for the complexes with respect to the free dipeptides. Similarly, a downfield-shift trend is detected also for the ${ }^{13} \mathrm{C}$ atoms directly bonded to the -NCSS moiety (Table S3), with a $\delta$ increase of about $7 \mathrm{ppm}$ on passing from the free peptides to the corresponding complexes.

The formation of the dithiocarbamato moiety is confirmed by the disappearance of the free amine proton signal of the hydrochloride dipeptide (usually occurring at 9.8-9.3 ppm, Table 1) and by the appearance of the dithiocarbamato carbon atom resonance at about 200 ppm (Table S3), in agreement with literature data for complexes with high-oxidation state metals. ${ }^{[56]}$ Both the ${ }^{1} \mathrm{H}$ and the $\left[{ }^{1} \mathrm{H},{ }^{13} \mathrm{C}\right]-\mathrm{HMBC}$ NMR spectra of the complexes (the spectra of the complex IT01 are reported as an example in Figures S5, S6 and S7) show a double resonance for the nuclei within or closest to the dithiocarbamic moiety (e.g., the dithiocarbamic carbon -CSS at about 200 ppm and the protons of the $\mathrm{N}-\mathrm{CH}_{3}$ and $\mathrm{N}-\mathrm{CH}_{2}$ groups of the sarcosine residue in Figure S7), as already observed for similar compounds. ${ }^{[13,14]}$ This phenomenon was recently explained by the presence of two different isoforms of the compounds (in dynamic equilibrium in solution). ${ }^{[57]}$

Table 1. ${ }^{1} \mathrm{H}$ NMR spectral data of the starting dipeptides $\mathrm{P} 1-\mathrm{P} 5\left(\mathrm{HCl} \cdot \mathrm{H}-\mathrm{AA}_{1}\right.$ $A A_{2}-O R: A A_{1}=$ Sar, L/D-Pro; $\left.A A_{2}=D / L-A l a, A i b ; R=-t B u, T E G\right)$ and the corresponding gold(III)-dithiocarbamato derivatives IT01-IT05 ([ $\mathrm{Au}^{\mathrm{III}} \mathrm{Br}_{2}$ (dtc$\left.\mathrm{AA}_{1}-\mathrm{AA}_{2}-\mathrm{OR}\right]$ ) (DMSO-d $, 298 \mathrm{~K}, 300 \mathrm{MHz}$ ).

\begin{tabular}{|c|c|c|c|c|}
\hline \multirow{2}{*}{$\begin{array}{l}\text { Compo } \\
\text { und }\end{array}$} & \multicolumn{4}{|c|}{$\delta\left({ }^{1} \mathrm{H}\right)[p p m]$} \\
\hline & -OR & $\mathrm{AA}_{1}$ & $\mathrm{AA}_{2}$ & $-\mathrm{NH}_{2}{ }^{+}$ \\
\hline & $R=t B u$ & $\mathrm{AA}_{1}=\mathrm{Sar}$ & $\mathrm{AA}_{2}=\mathrm{L}-\mathrm{Ala}$ & \\
\hline \multirow{3}{*}{ P1 } & $1.40\left(-\mathrm{C}\left(\mathrm{CH}_{3}\right)_{3}\right)$ & $2.53\left(\mathrm{~N}-\mathrm{CH}_{3}\right)$ & $1.28\left(\beta-\mathrm{CH}_{3}\right)$ & 9.00 \\
\hline & & $3.70\left(\mathrm{~N}-\mathrm{CH}_{2}\right)$ & $4.17(\alpha-C H)$ & \\
\hline & & & $8.88(\mathrm{NH})$ & \\
\hline \multirow[t]{4}{*}{ IT01 } & $1.40\left(-\mathrm{C}\left(\mathrm{CH}_{3}\right)_{3}\right)$ & $3.37\left(\mathrm{~N}-\mathrm{CH}_{3}\right)$ & $1.23\left(\beta-\mathrm{CH}_{3}\right)$ & - \\
\hline & & $4.53\left(\mathrm{~N}-\mathrm{CH}_{2}\right)$ & $4.18(\alpha-C H)$ & \\
\hline & & & $8.79(\mathrm{NH})$ & \\
\hline & $\mathrm{R}=t \mathrm{Bu}$ & $\mathbf{A A}_{1}=\mathrm{Sar}$ & $\mathrm{AA}_{2}=\mathrm{D}-\mathrm{Ala}$ & \\
\hline \multirow[t]{3}{*}{ P2 } & $1.40\left(-\mathrm{C}\left(\mathrm{CH}_{3}\right)_{3}\right)$ & $2.52\left(\mathrm{~N}-\mathrm{CH}_{3}\right)$ & $1.27\left(\beta-\mathrm{CH}_{3}\right)$ & 9.12 \\
\hline & & $3.69\left(\mathrm{~N}-\mathrm{CH}_{2}\right)$ & $4.16(\alpha-C H)$ & \\
\hline & & & $8.96(\mathrm{NH})$ & \\
\hline \multirow[t]{4}{*}{ IT02 } & $1.41\left(-\mathrm{C}\left(\mathrm{CH}_{3}\right)_{3}\right)$ & $3.36\left(\mathrm{~N}-\mathrm{CH}_{3}\right)$ & $1.28\left(\beta-\mathrm{CH}_{3}\right)$ & - \\
\hline & & $4.53\left(\mathrm{~N}-\mathrm{CH}_{2}\right)$ & $4.17(\alpha-C H)$ & \\
\hline & & & $8.79(\mathrm{NH})$ & \\
\hline & $R=t B u$ & $\mathrm{AA}_{1}=\mathrm{L}-$ Pro & $\mathrm{AA}_{2}=\mathrm{Aib}$ & \\
\hline \multirow[t]{4}{*}{ P3 } & $1.32\left(-\mathrm{C}\left(\mathrm{CH}_{3}\right)_{3}\right)$ & $\begin{array}{l}1.83\left(\mathrm{CH}^{3 \prime \prime}\right. \\
\left.\mathrm{CH}_{2}{ }^{4}\right)\end{array}$ & $1.36\left(\beta-\mathrm{CH}_{3}\right)$ & 9.80 \\
\hline & & $2.27\left(\mathrm{CH}^{3 \prime}\right)$ & $8.92(\mathrm{NH})$ & \\
\hline & & $3.15\left(\mathrm{CH}_{2}^{5}\right)$ & & \\
\hline & & $4.11\left(\mathrm{CH}^{2}\right)$ & & \\
\hline \multirow[t]{5}{*}{ IT03 } & $1.38\left(-\mathrm{C}\left(\mathrm{CH}_{3}\right)_{3}\right)$ & $\begin{array}{l}2.08\left(\mathrm{CH}^{3 \prime \prime}\right. \\
\left.\mathrm{CH}_{2}{ }^{4}\right)\end{array}$ & $1.33\left(\beta-\mathrm{CH}_{3}\right)$ & - \\
\hline & & $2.41\left(\mathrm{CH}^{3 \prime}\right)$ & $8.75(\mathrm{NH})$ & \\
\hline & & $3.88\left(\mathrm{CH}_{2}^{5}\right)$ & & \\
\hline & & $4.76\left(\mathrm{CH}^{2}\right)$ & & \\
\hline & $R=t B u$ & $\mathrm{AA}_{1}=\mathrm{D}-$ Pro & $\mathrm{AA}_{2}=\mathrm{Aib}$ & \\
\hline \multirow[t]{4}{*}{ P4 } & $1.37\left(-\mathrm{C}\left(\mathrm{CH}_{3}\right)_{3}\right)$ & $\begin{array}{l}1.83\left(\mathrm{CH}^{3 \prime \prime}\right. \\
\left.\mathrm{CH}_{2}^{4}\right)\end{array}$ & $1.37\left(\beta-\mathrm{CH}_{3}\right)$ & 9.34 \\
\hline & & $2.29\left(\mathrm{CH}^{3 \prime}\right)$ & $8.94(\mathrm{NH})$ & \\
\hline & & $3.15\left(\mathrm{CH}_{2}{ }^{5}\right)$ & & \\
\hline & & $4.14\left(\mathrm{CH}^{2}\right)$ & & \\
\hline \multirow[t]{4}{*}{ IT04 } & $1.38\left(-\mathrm{C}\left(\mathrm{CH}_{3}\right)_{3}\right)$ & $\begin{array}{l}2.10\left(\mathrm{CH}^{3 \prime \prime},\right. \\
\left.\mathrm{CH}_{2}{ }^{4}\right)\end{array}$ & $1.31\left(\beta-\mathrm{CH}_{3}\right)$ & - \\
\hline & & $2.41\left(\mathrm{CH}^{3 \prime}\right)$ & $8.78(\mathrm{NH})$ & \\
\hline & & $3.89\left(\mathrm{CH}_{2}{ }^{5}\right)$ & & \\
\hline & & $4.76\left(\mathrm{CH}^{2}\right)$ & & \\
\hline
\end{tabular}




\begin{tabular}{|c|c|c|c|c|}
\hline \multirow{3}{*}{ P5 } & T=TEG & $\mathrm{AA}_{1}=\mathrm{Sar}$ & $\mathrm{AA}_{2}=\mathrm{Aib}$ & \multirow[b]{2}{*}{9.04} \\
\hline & $3.24\left(\mathrm{O}-\mathrm{CH}_{3}\right)$ & $2.51\left(\mathrm{~N}-\mathrm{CH}_{3}\right)$ & $1.39\left(\beta-\mathrm{CH}_{3}\right)$ & \\
\hline & $3.41-3.54$ & $3.66\left(\mathrm{~N}-\mathrm{CH}_{2}\right)$ & $9.04(\mathrm{NH})$ & \\
\hline & $\left(\mathrm{CH}_{2}^{3,4,5,6}\right)$ & & & \\
\hline & $3.57-3.60\left(\mathrm{CH}_{2}^{2}\right)$ & & & \\
\hline & 4.10-4.13 $\left(\mathrm{CH}_{2}{ }^{1}\right)$ & & & \\
\hline \multirow[t]{5}{*}{ IT05 } & $3.24\left(\mathrm{O}-\mathrm{CH}_{3}\right)$ & $3.57\left(\mathrm{~N}-\mathrm{CH}_{3}\right)$ & $1.39\left(\beta-\mathrm{CH}_{3}\right)$ & - \\
\hline & 3.36-3.58 & $4.47\left(\mathrm{~N}-\mathrm{CH}_{2}\right)$ & $8.83(\mathrm{NH})$ & \\
\hline & $\left(\mathrm{CH}_{2}{ }^{3,4,5,6}\right)$ & & & \\
\hline & 3.62-3.65 $\left(\mathrm{CH}_{2}{ }^{2}\right)$ & & & \\
\hline & 4.10-4.11 $\left(\mathrm{CH}_{2}^{1}\right)$ & & & \\
\hline
\end{tabular}

\section{Crystal Structures}

The complexes IT05, the racemate IT03/IT04 and the urethaneprotected precursor of a peptide ligand, namely Z-L-Pro-Aib-OtBu, were characterized by single crystal $\mathrm{X}$-ray diffraction analysis.

The molecular structure of IT05 is reported in Figure 2. The metal exhibits a square planar geometry achieved by the $S, S$ chelate dithiocarbamato (dtc) ligand and by two bromide. The coordination environment of the metal and the coordination distances (Tables S4-S5) are in agreement with previously reported data for gold complexes with a dtc ligand and two bromide ligands. The peripheral methylated triethylene glycol is folded towards the dtc moiety and the three ethereal oxygen atoms, $\mathrm{O}(4)-\mathrm{O}(6)$, are capping the $\mathrm{C}(2)$ methyl group of the dtc ligand. The crystal packing shows that the IT05 molecules are irregularly stacked along the b crystallographic axis (Figure S8), and that the long arm of the ligand originating from the $\mathrm{C}(3)$ atom, is responsible of several $\mathrm{C}-\mathrm{H} \cdots \mathrm{O}$ interactions (Figure S9). In addition, there is a bifurcated hydrogen bond between the $\mathrm{N}(2)-\mathrm{H}$ and the $\mathrm{O}(4)$ ' and $\mathrm{O}(5)$ ' atoms of a symmetry related triethylene glycol residue (symmetry code $=1 / 2-\mathrm{x} ; 1 / 2+\mathrm{y} ; \mathrm{z}$ ), $\mathrm{d}\left[\mathrm{N}(2) \cdot \cdot \mathrm{O}(4)^{\prime}\right]=$ $3.00(3) \AA$, and $d\left[\mathrm{~N}(2) \cdot \cdot \mathrm{O}(5)^{\prime}\right]=3.18(4) \AA$, which is mainly responsible for the conformations adopted by the methylated triethylene glycol.
Figure 2. Molecular structure of [Au"l'Br 2 (dtc-Sar-Aib-OTEG)] (IT05). CCDC Number: 1001852; CIF data block name: data_it05pen; Formula: C15 H27 Au1 Br2 N2 O6 S2; Unit Cell: a 22.15(2) b 9.599(9) c 25.88(2); Space Group: Pbcn.

Attempts to grow single crystals from the chiral compound IT03 were fruitless. We therefore decided to explore the racemic crystallography approach, based on the principle that, in general, racemates are more easily amenable to crystallization than the corresponding enantiopure compounds. ${ }^{[58-61]}$ Equimolar amounts of the two enantiomers IT03 and IT04 were combined for crystallization experiments, one of which (from acetone) was successful. In the structure of the racemate IT03/IT04 (Figure 3), the planar square geometry and the metal coordination distances (Tables S6-S7) closely match those observed for IT05. The $\mathrm{C}^{\alpha}$ and $\mathrm{C}^{\delta}$ atoms of the Pro residue are coplanar to the sulfur atoms. In the $L$ enantiomer, taken as the asymmetric unit, the values of backbone torsion angles of the peptide moiety are indicative of a semi-extended [or poly(Pro ${ }_{n}$ II] conformation for the Pro residue, while right-handed helical for Aib. The Aib $\mathrm{N}-\mathrm{H}$ group is $\mathrm{H}$-bonded to the $\mathrm{C}=\mathrm{O}$ group of a disordered, co-crystallized acetone molecule within the same asymmetric unit. In the packing mode, acetone molecules occupy infinite channels that run parallel to the $b$ direction (Figure S10)

The X-ray diffraction structure of Z-L-Pro-Aib-OtBu has been solved as well (Supporting Information, Figure S11 and Tables S8-S10). Interestingly, the conformations adopted by the L-Pro and Aib residues are very similar to those observed for the Lenantiomer of the racemate IT03/IT04.

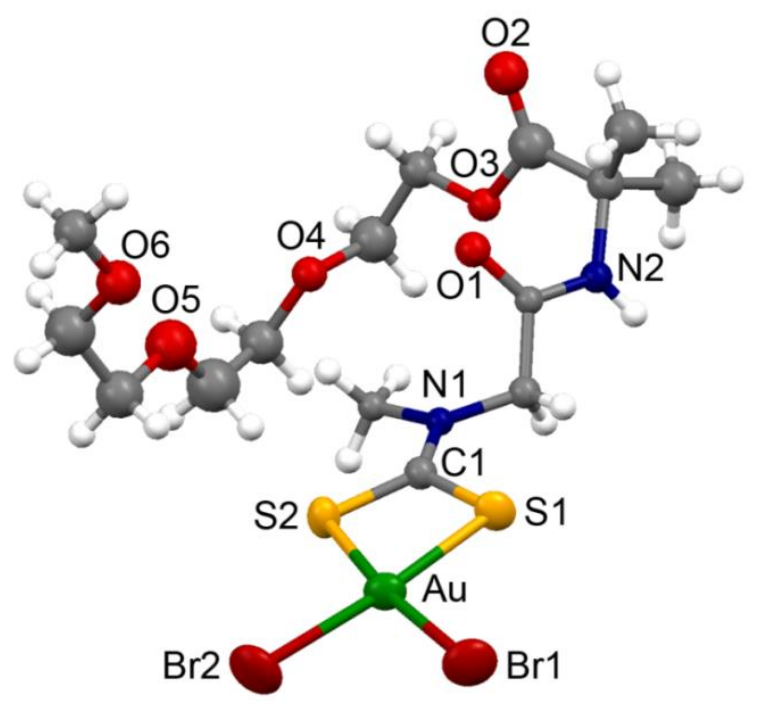






Figure 3. Molecular structure of $\mathrm{Au}^{\text {IIIBr}} \mathrm{Br}_{2}$ (dtc-L,D-Pro-Aib-OtBu (IT03/IT04). The $\mathrm{L}$ enantiomer is shown (IT03). $\mathrm{H}$-atoms have been omitted for clarity.

\section{UV-Vis analysis of stability under physiological conditions}

Since the compounds are not per se water soluble, all the biological assays have been performed via pre-dissolution in DMSO (at a final maximum concentration of $1 \% \mathrm{v} / \mathrm{v}$ ) prior to addition to cell culture medium. Among our gold(III)peptidedithiocarbamato derivatives, IT03 was chosen as a model compound for first evaluating the stability in pure DMSO (used as stock solution). The compound was dissolved in the organic solvent at a final concentration of $50 \mu \mathrm{M}$, and the UV-Vis spectra were recorded at $25^{\circ} \mathrm{C}$ in the range $190-800 \mathrm{~nm}$ over $24 \mathrm{~h}$ (Figure $\mathrm{S} 12)$. In this solvent, the complex shows three main absorption bands. The first two bands, hereinafter called band I and band II, are assigned from the literature to intraligand $\pi^{*} \leftarrow \pi$ transitions (at about 260 and $310 \mathrm{~nm}$ ) mainly located on the -NCS and -CSS moieties, respectively. ${ }^{[62-63]}$ An intraligand $\pi^{*} \leftarrow n$ transition (where $n$ is the in-plane non-bonding sulfur orbital) is expected around $340 \mathrm{~nm}$, but is not discernible due to overlap with higher intensity bands at very close wavelength. The third detectable band of weak intensity is rather found at higher wavelengths (around 370 $\mathrm{nm}$ ), and is assigned to an electron transfer of the type $u \leftarrow g$, from a $4 p$ orbital ( $\pi$ symmetry) of the bromide ligands to the lowest unfilled $5 d$ metal orbital (band III, Table S11). ${ }^{64]}$

No significant modification of the position and/or intensity of the bands was detected over $24 \mathrm{~h}$, thus highlighting the compound stability in this solvent. The only very slight variations observed are due to the presence of water in the system, which increases over time and results in partial hydrolysis of the complex. The bromide ligands are thus substituted by one/two water molecules to form the corresponding aquo complex, which is still quite water soluble. This phenomenon is associated with a slight shift in the wavelength of the two main absorption bands, which move towards the band positions recorded for the same complex in water (DMSO concentration $<5 \% \mathrm{v} / \mathrm{v}$ ).

Moving to aqueous systems, the behavior in pure deionized water was first evaluated, confirming the tendency of the complex to undergo partial hydrolysis, with slow modifications over the first $24 \mathrm{~h}$ (Figure S13). The main absorption bands present opposite trends, with band I and band II undergoing hypochromic and hyperchromic modifications with time, respectively. Simultaneously, a band at nearly $380 \mathrm{~nm}$ increases in intensity with time. All these changes are ascribed to the formation of the aquo-complex. Anyway, after nearly $10 \mathrm{~h}$, an hypochromic effect of the absorption bands II and III is detected, which can be correlated to the partial precipitation of the dihydroxo-complex (already described for other gold(III)-dithiocarbamato derivatives) ${ }^{[65]}$ which is less water soluble than the corresponding aquo complex. The compound, which precipitates as a yellow powdery solid, was isolated and characterized by means of elemental analysis and FT-IR spectroscopy, and finally identified as the hydroxo-derivative.

The behavior of the complex IT03 in saline solution $(0.9 \% \mathrm{w} / \mathrm{v}$ $\mathrm{NaCl}$ ) is slightly different compared to that recorded in pure water (Figure S14, Table S11). In this case, an hyperchromic effect is detected for both the bands I and II. The hyperchromic effect recorded for the two main bands can be explained with the substitution of the bromide ligands with chlorides, as a consequence of the higher concentration of $\mathrm{Cl}^{-}$ions in solution. Subsequently, the replacement of one/two chloride ligands with water molecules can lead to the formation of the mono/di-aquoderivative, as suggested by the appearance of an absorption band at $380 \mathrm{~nm}$ (metal-to-ligand charge transfer). However, in this case no precipitate was detected in solution over $24 \mathrm{~h}$.

The behavior of IT03 in PBS (phosphate buffered solution) is completely different with respect to the previous ones (Figure S15, Table S11). During the first $4 \mathrm{~h}$ from dissolution the complex undergoes fast hydrolysis and the dihydroxo complex precipitates as a yellow powdery solid. The more basic $\mathrm{pH}$ of the solution (buffered at 7.4) and the presence of phosphato ions can favor the formation and precipitation of the dihydroxo derivative and the corresponding phosphato-derivative.

Moving to more complex environments, the stability of the gold(III) complex in complete cell culture medium was analyzed. The electronic spectra, recorded in PBS added of $20 \% \mathrm{v} / \mathrm{v}$ complete medium (RPMI-1640 medium supplemented with $10 \%$ fetal calf serum), show two main absorption bands at 273 and $307 \mathrm{~nm}$, both assignable to the IT03 complex (Figure S16). In fact, the main absorption band of the medium itself is detectable at $276 \mathrm{~nm}$. The behavior of the complex in this environment is similar to that observed in PBS, even if a precipitate did not form in this case, probably as a consequence of the interaction of the complex with proteins or other medium components. Similarly to the previous spectra, an intensity reduction of the bands related to the $\pi^{*}$ $\pi$ transitions, is accompanied by an hyperchromic effect of the 
band at $362 \mathrm{~nm}$, correlated to the formation of gold-oxygen bonds (as already described above).

\section{Biological activity}

In vitro cytotoxicity. The compounds were tested on a broad panel of human cancer cell lines to assess their cytotoxic activity against different tumor types. The $\mathrm{Gl}_{50}$ values, summarized in Table 2, were calculated for each compound after a 72-h incubation as described in the Experimental section.

All the dipeptide-functionalized gold(III) complexes show a quite similar activity. Notably, overall the compounds present higher cytotoxic activity than Cisplatin for instance towards the human ovarian cancer $\mathrm{A} 2780$ cell line, with $\mathrm{Gl}_{50}$ values lower than $0.6 \mu \mathrm{M}$, thus resulting about 10 to 20 times more effective than the reference metallodrug. Interestingly, very promising results were obtained also with $\mathrm{H} 1975$ cells from human non-small cell lung cancer, with most $\mathrm{Gl}_{50}$ values in the submicromolar range. The compounds are also moderately active against the breast adenocarcinoma MCF-7 ( $\mathrm{Gl}_{50}$ values about 5 -fold lower than that recorded after Cisplatin treatment).

Among the tested complexes, IT03 and IT04 are the most active with an antiproliferative activity comparable to - in some cases higher than - that of Cisplatin. Interestingly, IT05 seems less potent than the other members of the series, for instance against the MCF-7 and H1975 cell lines. This could be ascribed to differences among the studied compounds in hydrophobicity and steric hindrance at the $C$-ter, IT05 bearing a TEG ester group instead of a tert-butyl one.

Taken together, the observed antiproliferative potency of the new complexes resulted comparable or slightly less pronounced than that of the "first generation" compound AuL12 ([Au"'Br $\left.r_{2}(E S D T)\right]$, $(E S D T=$ ethylsarcosinedithiocarbamate $)$ against all the tested cell lines.

Table 2. $\mathrm{Gl}_{50} \pm$ st.dev. $(\mu \mathrm{M})$ recorded after a $72-\mathrm{h}$ treatment against the $\mathrm{A} 549$ (human non-small cell lung carcinoma), MCF-7 (human breast cancer), A2780 (human ovarian carcinoma cells), H1975 (human non-small cell lung cancer), H460 (human large cell lung carcinoma) and A431 (human epidermoid carcinoma) cell lines for the compounds IT01-05, AuL12 and Cisplatin (taken as a reference). The data correspond to means of at least three experiments performed in quadruplicate \pm S.D.

\begin{tabular}{|c|c|c|c|c|c|c|c|}
\hline & \multicolumn{7}{|c|}{$\mathrm{Gl}_{50} \pm$ st.dev. $(\mu \mathrm{M})$} \\
\hline & IT01 & IT02 & IT03 & IT04 & IT05 & AuL12 & $\begin{array}{l}\text { Cispla } \\
\text { tin }\end{array}$ \\
\hline $\begin{array}{l}\text { A54 } \\
9\end{array}$ & $20 \pm 3$ & $27 \pm 3$ & $10 \pm 3$ & $9 \pm 2$ & $14 \pm 2$ & $12 \pm 2$ & $\begin{array}{l}8.0 \pm 0 . \\
5\end{array}$ \\
\hline $\begin{array}{l}\mathrm{MC} \\
\mathrm{F}-7\end{array}$ & $\begin{array}{l}3.4 \pm \\
0.9\end{array}$ & $\begin{array}{l}4.3 \pm \\
0.8\end{array}$ & $\begin{array}{l}4.0 \pm \\
0.7\end{array}$ & $3 \pm 2$ & $\begin{array}{l}8.5 \pm \\
0.9\end{array}$ & $6.4 \pm 0.7$ & $20 \pm 3$ \\
\hline $\begin{array}{l}\text { A27 } \\
80\end{array}$ & $\begin{array}{l}0.6 \pm \\
0.2 \\
\end{array}$ & $\begin{array}{l}0.3 \pm \\
0.2\end{array}$ & $\begin{array}{l}0.4 \pm \\
0.1 \\
\end{array}$ & $\begin{array}{l}0.2 \pm 0 . \\
1\end{array}$ & $\begin{array}{l}0.5 \pm \\
0.1 \\
\end{array}$ & $\begin{array}{l}0.40 \pm 0.0 \\
8\end{array}$ & $5 \pm 2$ \\
\hline $\begin{array}{l}\mathrm{H} 19 \\
75\end{array}$ & $\begin{array}{l}0.6 \pm \\
0.1 \\
\end{array}$ & $\begin{array}{l}0.6 \pm \\
0.2\end{array}$ & $\begin{array}{l}0.7 \pm \\
0.1\end{array}$ & $\begin{array}{l}0.66 \pm 0 \\
.06\end{array}$ & $6 \pm 1$ & $\begin{array}{l}0.158 \pm 0 . \\
008\end{array}$ & $\begin{array}{l}0.99 \pm 0 \\
.09\end{array}$ \\
\hline $\begin{array}{l}\mathrm{H} 46 \\
0\end{array}$ & $4 \pm 2$ & $\begin{array}{l}3.4 \pm \\
0.4 \\
\end{array}$ & $\begin{array}{l}3.6 \pm \\
0.5 \\
\end{array}$ & $\begin{array}{l}3.0 \pm 0 . \\
6\end{array}$ & $\begin{array}{l}4.3 \pm \\
0.2 \\
\end{array}$ & $2.2 \pm 0.3$ & $\begin{array}{l}0.8 \pm 0 . \\
1\end{array}$ \\
\hline $\begin{array}{l}\text { A43 } \\
1\end{array}$ & $16 \pm 4$ & $14 \pm 3$ & $8 \pm 3$ & $10 \pm 2$ & $13 \pm 3$ & $10 \pm 3$ & $\begin{array}{l}3.2 \pm \\
0.5\end{array}$ \\
\hline
\end{tabular}

Generally, the compounds differing only in the stereochemical configuration of the chiral amino acid ( $D, L$ enantiomers) in the dipeptide ligand, show similar cytotoxic activity (IT02 vs IT01 and IT04 vs IT03). This highlights that there is no correlation between the stereochemical features of the compounds and their cytotoxic activity and/or cell transporter recognition. Nevertheless, the PEPT selectivity for L-configuration derivatives is proved for naturally occurring aminoacids or oligopeptides but PEPTs are responsible also for the transport of peptido-mimetics which only resemble the main features of their physiological substrates, ${ }^{[14-19}$ ${ }^{51-53]}$ so it is possible that similar recognition occurs for both the gold(III) isomers regardless of their chirality. Anyway, deeper studies about the overexpression of PEPTs by the selected cell lines will be carried out to analyze if differences in the internalization rates of the two gold(III) enantiomers can be detected.

\section{Ex vivo toxicity}

Recently, the precision cut tissue slices technique was exploited to study the toxic effects of experimental anticancer organometallic compounds, ${ }^{[27-29]}$ aminoferrocene-containing prodrugs, ${ }^{[30]}$ ruthenium-based kinase inhibitors, ${ }^{[31]}$ as well as supramolecular metallacages as possible drug delivery systems. ${ }^{[32]}$ In this work, the toxicity of some selected complexes was tested using different tissues from rat organs ex vivo using the PCTS method. ${ }^{[25]}$ In these tests, thin slices of healthy tissue derived from organs excised from animals are incubated with drugs or other compounds. This method allows the study of drug metabolism and toxicity in intact tissues, with great advantages with respect to both in vitro cell culture and in vivo animal testing The use of slices results in a reduction of the number of animals used for the experiments, allowing the in-parallel assay of more than one compound at different concentrations. Moreover, although being an ex vivo context, the method has the advantage of using intact tissues where enzyme systems, cofactors and transporters are present at their physiological levels, resulting in a quite reliable model for the in vivo conditions. ${ }^{[54]}$

Based on the cellular screening (Table 2), the complex IT03 is one of the most promising and was thus selected as a model compound for the ex vivo toxicity experiments. Thus, the toxicity of IT03 and AuL12 were evaluated in healthy rat tissues (liver and colon) in comparison to Cisplatin, since these two organs are generally mainly involved in drug metabolism and excretion, respectively. Moreover, the compounds were also tested against kidney as this organ is usually strongly affected by treatment with Cisplatin in patients.

The compounds were incubated with slices and the viability of the tissues after a certain incubation time ( $24 \mathrm{~h}$ for liver and kidney, 5 $\mathrm{h}$ for colon slices, respectively) was determined measuring the ATP content as described in the Experimental section. For each experiment, control samples were also incubated with medium containing the maximum concentration of DMSO used in the test samples, so to determine any intrinsic toxic effect of the organic solvent on the slice viability. Notably, the concentration of DMSO added to the samples proved not toxic in all the analyzed organ tissues with tissue viability values comparable to those of control samples incubated with pure medium (data not shown). Overall, 
the gold complexes displayed a concentration-dependent toxicity profile with $\mathrm{TC}_{50}$ values higher than Cisplatin (Table 3 ), made exception for colon slices. Furthermore, it should be noted that the compounds show also markedly less toxic effects in kidney slices with respect to the anti-rheumatic gold-based drug and potent cytotoxic agent auranofin. ${ }^{[70]}$

Table 3. Toxicity (TC50 values) of the gold complexes IT03 and AuL12 in comparison to Cisplatin against liver, colon and kidney slices. The data are mean $( \pm S D)$ values from at least three independent experiments.

\begin{tabular}{llll}
\hline \multicolumn{4}{c}{ TC $_{50} \pm$ st.dev. $(\mu \mathrm{M})$} \\
\hline Organ & IT03 & AuL12 & Cisplatin \\
\hline Liver & $37 \pm 7$ & $44 \pm 6$ & $25 \pm 2$ \\
Colon & $38 \pm 9$ & $51 \pm 10$ & $>100$ \\
Kidney & $43 \pm 9$ & $53 \pm 9$ & $13 \pm 2$
\end{tabular}

Interaction with PARP-1 enzyme.

Based on previous studies involving other gold(III) dithiocarbamato compounds, some biologically-relevant targets were identified including thioredoxin reductase (TrxR) and proteasome enzymes. ${ }^{[11,15,54,71]}$ For this class of complexes, DNA does not seem a major target, despite the great affinity for the isolated DNA molecule and the capability to inhibit both RNA and DNA synthesis in a non dose-dependent way, differently from what recorded for Cisplatin. ${ }^{[11]}$ Nonetheless, other proteins involved in DNA repair and regulation mechanisms could be affected by the treatment with our new anticancer agents. Within this framework we investigated the interaction of the compounds IT03 and AuL12 (our reference "first generation" complex) with PARP-1, a zinc-finger protein essential for the DNA repair process and with a key role in the mechanisms of cancer cell resistance to Cisplatin.

Among the PARP inhibitors worldwide studied, Olaparib (Lynparza $^{\circledR}$, AstraZeneca), showed an $\mathrm{IC}_{50}$ value of $0.005 \mu \mathrm{M}$ in the in vitro inhibition of the PARP-1 enzyme, ${ }^{[40]}$ and is now approved by the US Food and Drug Administration for the treatment of advanced ovarian cancer in patients with germline BRCA-mutations. It is also under clinical studies for the treatment of triple negative breast cancer and metastatic castrationresistant prostate cancer. In this context, it is worth highlighting that nuclear levels of PARP-1 have been directly correlated to the stage of progression of the malignant transformation, representing a parameter to predict poor prognosis. ${ }^{[41]}$ In addition, PARP-1 is directly involved in the angiogenic process ${ }^{[42]}$ and contributes to the regulation of important transcription factors, such as NFkB, ${ }^{[43-45]}$ whose overexpression is connected to neoplasia progression and malignancy.

Our gold compounds were tested as inhibitors of PARP-1 (purified protein) as previously reported, and the collected values (Figure 4) were compared with those obtained for Cisplatin and the inhibitor Olaparib ${ }^{\circledR} \cdot{ }^{[40]}$ It is worth mentioning that while the gold complexes could be incubated for only $1 \mathrm{~h}$ with PARP-1 due to their fast kinetic of ligand exchange, Cisplatin required at least 24 $\mathrm{h}$ to reach the maximum of inhibition.

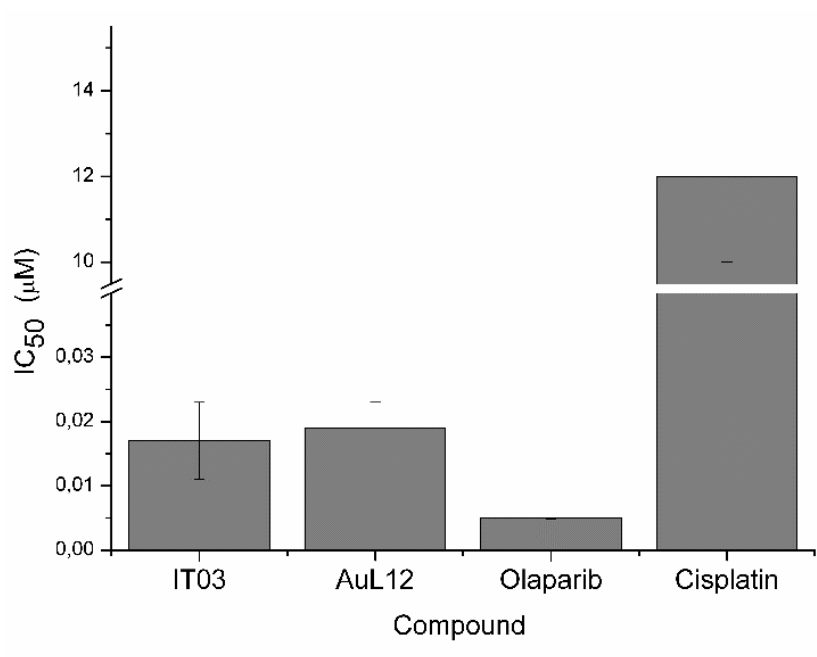

Figure 4. Inhibition of the PARP-1 activity by test compounds, also reported in Table S12 The data correspond to means of at least three experiments performed in triplicate \pm S.D.

Both our gold(III)-dithiocarbamato complexes IT03 and AuL12 proved good inhibitors of the purified PARP-1 enzyme, with similar $\mathrm{IC}_{50}$ values in the nanomolar range (Figure S17), in accordance with previously reported results on other families of $\mathrm{Au}(\mathrm{III})$ complexes. ${ }^{[35,37]}$ Interestingly, the results collected after 1-h incubation for the gold(III) compounds are comparable to those obtained for the PARP-1 inhibitor Olaparib ${ }^{\circledR}$ after 24 hours of incubation, thus highlighting a high and fast reactivity of our compounds towards this DNA repair protein.

If comparing the results obtained for the new compound IT03 with Cisplatin, of which $\mathrm{IC}_{50}$ is about 700 -fold higher, with this work we find again differences in terms of biological targets and/or mechanism of action between our gold(III) complexes and the reference anticancer metallodrug.

\section{Interaction with BSA}

In drug development, it is essential to analyze the interaction of the best selected compound with serum albumins as they are the most abundant proteins in the circulatory system $(30-50 \mathrm{~g} / \mathrm{L}$ in the human serum, $52-60 \%$ of plasma protein composition). ${ }^{[72]}$ Albumins play a fundamental role not only in the control of the osmotic blood pressure, but also in the transport of various endogenous compounds, such as fatty acids, hormones, toxic metabolites (e.g., bilirubin), bile acids and amino acids. In recent years, the human serum albumin (HSA) has been emerging as a reliable and versatile carrier for therapeutic and diagnostic agents, owing to its small size, flexibility and high abundance in the plasma. ${ }^{73-74]}$

Compared to HSA, the more easily available bovine serum albumin (BSA) shares a sequence homology of $76 \%$, and is constituted by a single polypeptide chain of 583 amino acid residues, having molecular weight of about $66 \mathrm{kDa}$ and a secondary structure predominantly in the $\alpha$-helix form (74\%, PDB: 3 V03). Both proteins show the presence of a Trp in the subdomain IIA (W214 for HSA and W213 for BSA). The fundamental difference between HSA and BSA consists mainly in an additional 
tryptophan residue (W134) located on the surface of the BSA protein. ${ }^{[75]}$

Considering the pharmacokinetic and pharmacological implications, the study of the interaction between new molecular entities and the BSA (taken as a model) becomes of great importance. In this regard, for many drugs and prodrugs it was demonstrated that this carrier protein plays a crucial role in their stabilization and transport, modulating their bioavailability and toxicity. ${ }^{76]}$ In fact, i.v. administered metal-based therapeutics likely interact with serum albumin. Platinum-based drugs bind to HSA, thus affecting their metabolism, body distribution and activity. ${ }^{[76,77]}$ Indeed, the protein contains six methionine residues (i.e., Met-87, 123, 298, 329, 446, and 548) among which the Met298 is the most accessible on the surface and identified as the main cisplatin-binding site. ${ }^{[78]}$ In the literature, there are other examples of studies of interaction between metal-based agents and serum albumin. ${ }^{[79,80]}$

In this work, the possible interaction of the compound IT03 with BSA was investigated by different spectrophotometric techniques, namely fluorescence, UV-Vis and CD. First, the compound was incubated with BSA at equimolar ratio $(30 \mu \mathrm{M})$, and electronic spectra were recorded over time. The UV-Vis spectrum of BSA is characterized by two main absorption bands at 198 and $280 \mathrm{~nm}$, which correspond to $\pi^{*} \leftarrow \pi$ transitions located on the peptide moiety and the aromatic ring of the aminoacids Trp and Tyr, respectively. In the UV-Vis spectrum recorded soon after the start of incubation, the main absorption bands previously described for IT03 are detected, with the band I almost overlapping to the BSA absorption at $280 \mathrm{~nm}$ (Figure S18).

Upon incubation with BSA, no stabilizing effect (able to reduce the complex hydrolysis rate) seems to take place, as an hypochromic effect is observed for both bands I and II. This is paralleled by a slight increase in band intensity at $360 \mathrm{~nm}$, probably due to complex-protein interactions via metal coordination, thus preventing the precipitation of the hydrolized compound.

The interaction with BSA was analyzed also by circular dichroism by observing possible secondary-structure modifications upon incubation with the complex. The CD spectra recorded soon after the incubation of IT03 (after pre-dissolution in DMSO; final DMSO concentration $<1.5 \mathrm{v} / \mathrm{v} \%)$ with BSA $(15 \mu \mathrm{M})$ in PBS solution at different molar ratios (Figure $\mathrm{S19}$ ) showed variations in the protein secondary structure which were significant only at IT03:BSA molar ratio of 1 or higher. These spectral modifications can be correlated with a more extended conformation, or to an increase in $\beta$-sheet or random contributions to the structure. Anyway, this behavior is detectable only at high complex concentrations (with respect to BSA) that are far from the physiological-like conditions.

Further studies, aimed at elucidating the results obtained with the CD experiments, were carried out recording fluorescence spectra at constant temperature $\left(25^{\circ} \mathrm{C}\right)$ at the same concentrations and time ranges reported above. In this regard, it is known that the intrinsic fluorescence of BSA stems from two tryptophan (Trp) residues per chain which are known to be excellent structural probes. ${ }^{[81-83]}$ They are characterized by strong emission signals at room temperature and are very sensitive to the local environment. One residue is buried (W213) inside the protein whereas the second one is located on the protein surface (W134). Thus, a change in either fluorescence intensity or emission band position can be correlated to a structural modification upon interaction with the metal-based agent.

Here, in the first experiment the molar ratio between protein and IT03 was kept constant $(1: 1 ; 15 \mu \mathrm{M})$, and the fluorescence spectra were recorded at different times, starting from incubation over 24 h. The Figures S20 and S21 show that there is a progressive quenching of the BSA fluorescence intensity with time. Such a behavior may result from a direct interaction of the coordination compound with the protein fluorophores or from an increasing amount of endogenous quenchers, such as water molecules or oxygen, approaching the fluorescent sites. Only slight modifications in terms of fluorescence intensity were detected while keeping the band position unaffected. Taken together, these results highlight that no important changes occur in the environmental polarity or rigidity of the two Trp upon interaction with IT03 at equimolar conditions. Therefore, the experiment was repeated changing the IT03/BSA molar ratio, recording the fluorescence spectra soon after the incubation at constant temperature of $25^{\circ} \mathrm{C}$ (Figures S22 and S23). In this case, a quite marked decrease in the fluorescence intensity was detected with increasing the amount of IT03 (the DMSO content was kept constant for each sample). This phenomenon may be ascribed to either the direct interaction of the Trp134/213 with the metalbased compound or to interactions of the compound with other sites of the protein, resulting in changes in local domains of the BSA structure, thereby justifying the observed decrease of the quantum yield. Based on the analysis of the spectra reported in Figure S22, it is worth noting that negligible modifications are recorded for IT03:BSA molar ratios equal to or lower than 1 (mimicking the physiological conditions), thus suggesting that only a weak interaction takes place between the gold(III) complex and the protein.

\section{Conclusions}

In this work, we have preliminarily analyzed the role of the amino acid chirality in the biological response of the compounds along with the effect of substituting the Sar residue with another amino acid, Pro, being a derivative containing a secondary cyclic amine. Among the tested complexes, IT03 and IT04 proved the most promising with an antiproliferative activity comparable or sometimes greater than that of Cisplatin. Similar cytotoxic activity was recorded for all the investigated $D$, $L$ enantiomers.

IT03 was taken as a model compound for subsequent studies and its solution stability was evaluated in order to understand the possible modifications occurring in different aqueous systems mimicking the physiological conditions. The compound (previously solubilized in DMSO) behaves differently depending on the conditions. Indeed, IT03 undergoes hydrolysis both in pure water and in saline solution, by exchanging the bromido ligands with water molecules. Conversely, upon dissolution in PBS, the rapid formation of the hydroxo-derivative (not water-soluble) was detected. Anyway, when considering the cell culture medium, the precipitation of the hydroxo-derivative is reduced, likely due to the 
interaction of the compound with biomolecules and proteins present in the medium.

It has been of fundamental importance for the forthcoming in vivo experiments to preliminarily evaluate if the main serum component can favor or interfere with the IT03 distribution and activity. In light of the collected results, IT03 does not significantly modify the secondary structure of the chosen model protein when incubated at low molar ratios, being representative of the physiological conditions. The slight modifications in serum albumin structure may be due to weak secondary interactions with the gold(III) complex, thus making HSA a possible carrier for our compounds in vivo.

With respect to ex vivo studies, our results show that IT03 is less toxic than Cisplatin against rat liver and kidney tissues. Notably, concerning the liver, our gold(III) complex displayed about 50\% lower toxicity compared to the reference drug.

To date, the results collected for the gold-based anticancer agents point out the involvement of other biochemical pathways and cell targets with respect to Pt-based compounds. ${ }^{[11,35,84,85]}$ In this work, the studied $\mathrm{Au}(\mathrm{III})$ complexes proved potent fast PARP-1 inhibitors and future experiments will be aimed at the target validation in more complex cellular environments, as well as at the elucidation whether cellular uptake actually occurs by PEPT transporters.

\section{Experimental Section}

\section{Materials}

Acetone- $\mathrm{d}_{6}$, DMSO- $\mathrm{d}_{6}$, dichloromethane- $\mathrm{d}_{2}$, chloroform- $\mathrm{d}_{1}$, methanol- $\mathrm{d}_{4}$, 4-dimethylaminopyridine (DMAP), triethylene glycol monomethyl ether (TEG-OH) (Sigma Aldrich); 1-hydroxy-1H-benzotriazole (HOBt), phosphoric anhydride $\mathrm{P}_{2} \mathrm{O}_{5}, \mathrm{H}$-D-AlaOH, H-D-ProOH (Acros-Janssen); potassium tetrabromoaurate(III) dihydrate (Alfa Aesar); potassium hydrogen carbonate $\mathrm{NaHCO}_{3}$, potassium hydrogen sulphate $\mathrm{KHSO}_{4}$, sodium carbonate dodecahydrate, sodium hydroxide, sodium hypochlorite, sodium sulphate anhydrous, triethylamine (TEA, Carlo Erba); isobutene (Siad); isobutylchloroformiate (Lancaster); $\mathrm{N}$-methylmorpholine (NMM), palladium (10\% on carbon), HSarOH (Fluka); 1-ethyl-3-(3dimethylaminopropyl)-carbodiimide hydrochloride (EDC), N(benzyloxycarbonyloxy)succinimide (ZOSu, Iris Biotech); Z-Aib-OH, Z-LAla-OH, Z-L-Pro-OH, Z-Sar-OH (synthesized in Prof. Formaggio laboratory, University of Padua). All other reagents and solvents were used as purchased without any further purification.

\section{Instrumentation}

Elemental analysis. Elemental analysis of carbon, nitrogen and hydrogen were obtained with a CARLO ERBA mod $1108 \mathrm{CHNS}-\mathrm{O}$ microanalyzer.

Termogravimetric analysis. Thermogravimeter analysis (TG) and differential scanning calorimetry (DSC) were carried out using a thermoanalyzer NETZSCH mod. STA42 in the range $25-1200^{\circ} \mathrm{C}$ in alumina crucibles, with an heating rate of $5^{\circ} \mathrm{C} / \mathrm{min}$ under air, with a flow rate of $30 \mathrm{~cm}^{3} / \mathrm{min}$, using alumina as a reference substance.

Thin layer chromatography. Silica gel 60 F254 (Merck) or Alugram® Sil G UV 254 (Macherey-Nagel) on aluminium foil was used to follow the reactions. Silica gel 60 F254 (Merck) on glass was used for TLC characterization. Retention factors $\left(R_{t}\right)$ have been measured using three different solvent mixtures as eluents. $\mathbf{R}_{\mathrm{f} 1}: \mathrm{CHCl}_{3} / \mathrm{EtOH}$ 9:1; $\mathbf{R}_{\mathbf{f 2}}$ :
$\mathrm{BuOH} / \mathrm{AcOH} / \mathrm{H}_{2} \mathrm{O}$ 3:1:1; $\mathbf{R}_{\mathbf{f} 3}:$ PhMe/EtOH 7:1. Products were detected either by UV lamp irradiation, or with exposition to $I_{2}$ vapours or by warming with a heat gun and spraying firstly with a $1.5 \% \mathrm{NaClO}$ solution and then with a ninhydrin-TDM solution.

Flash chromatography. For flash chromathography (FC) purifications, silica gel 60 Merck (40-63 $\mu \mathrm{m}$ diameter, mesh 230-400) was used. The crude product was directly loaded on top of the column, after being dissolved in a small amount of the eluent used for the purification.

Polarimetric measurements. Optical rotations were measured on a PerkinElmer model 241 polarimeter with an Haake model D8 thermostat at the mercury line wavelength, using a cell with an optical pathlength of $10 \mathrm{~cm}$ Concentrations are expressed in $\mathrm{g} / 100 \mathrm{~mL}$. [a] are calculated using the formula $[\alpha]=\alpha /(c \cdot l)$, where "c" is the concentration (in $\mathrm{g} / \mathrm{mL}$ ) and "l" is the optical path (in $\mathrm{dm}$ ). Spectrophotometric grade $\mathrm{MeOH}$ was used as solvent.

IR Spectrophotometry. FT-IR spectra were recorded in nujol on a Nicolet Nexus 870 spectrophotometer (1000 scans, resolution $2 \mathrm{~cm}^{-1}$ ) for the range $50-600 \mathrm{~cm}^{-1}$, and in solid $\mathrm{KBr}$ on either a Nicolet $55 \mathrm{XC}$ or a PerkinElmer 580B spectrophotometer (32 scans, resolution $2 \mathrm{~cm}^{-1}$ ) for the range $400-4000 \mathrm{~cm}^{-1}$. Data processing was carried out using OMNIC version 5.1 (Nicolet Instrument Corp.).

NMR Spectroscopy. All NMR spectra were acquired in the appropriate deuterated solvent at $298 \mathrm{~K}$ on a Bruker Avance DRX 300 spectrometer using a $\mathrm{BBI}\left[{ }^{1} \mathrm{H}, \mathrm{X}\right]$ probe-head equipped with $z$-field gradients. Data processing was carried out using MestReNova version 6.2 (Mestrelab Research S.L.). Typical acquisition parameters for $1 \mathrm{D}{ }^{1} \mathrm{H}$ NMR spectra $(1 \mathrm{H}: 300.13 \mathrm{MHz}$ ): 16 transients, spectral width $7.5 \mathrm{kHz}$, using 32k data points and a delay time of $5.0 \mathrm{~s}$. Spectra were processed using exponential weighting with a resolution of $0.5 \mathrm{~Hz}$ and a line-broadening threshold of $0.1 \mathrm{~Hz}$. Typical acquisition parameters for $1 \mathrm{D}^{13} \mathrm{C}\left\{{ }^{1} \mathrm{H}\right\}$ NMR spectra $\left({ }^{13} \mathrm{C}\right.$ : $75.48 \mathrm{MHz}$ ): $8 \mathrm{k}$ transients, spectral width $18.8 \mathrm{kHz}$, using $32 \mathrm{k}$ data points and a delay time of $7.0 \mathrm{~s}$. Sequences were optimized for ${ }^{1} J\left({ }^{13} \mathrm{C},{ }^{1} \mathrm{H}\right)=145$ $\mathrm{Hz}$, and ${ }^{1} \mathrm{H}$ decoupling was achieved by using WALTZ16 pulse sequence. Spectra were processed using exponential weighting with a resolution of $2.0 \mathrm{~Hz}$ and a line-broadening threshold of $2.8 \mathrm{~Hz}$. Typical acquisition parameters for $2 \mathrm{D}\left[{ }^{1} \mathrm{H},{ }^{13} \mathrm{C}\right] \mathrm{HMBC}$ NMR spectra $\left({ }^{1} \mathrm{H}\right.$ : $300.13 /{ }^{13} \mathrm{C}: 75.48$ $\mathrm{MHz}$ ): 512 transients of 16 scans/block, spectral width $7.5 / 18.8 \mathrm{kHz}, 1 \mathrm{k} / 1 \mathrm{k}$ data points and a delay time of $2.0 \mathrm{~s}$. Sequences were optimized for ${ }^{1} \mathrm{~J}\left({ }^{13} \mathrm{C},{ }^{1} \mathrm{H}\right)=145 \mathrm{~Hz} /{ }^{n} \mathrm{~J}\left({ }^{13} \mathrm{C},{ }^{1} \mathrm{H}\right)=5 \mathrm{~Hz}$ with no ${ }^{1} \mathrm{H}$ decoupling. Spectra were processed by using sine-square weighting with a resolution of $0.3 / 1.0 \mathrm{~Hz}$ and a line-broadening threshold of $0.3 / 1.0 \mathrm{~Hz}$.

UV-Vis spectrophotometry. Electronic spectra were recorded using a Cary 100 Spectrophotometer (Agilent Technologies) in the range 200-800 nm (250-800 $\mathrm{nm}$ for aqueous samples containing DMSO), at a scan rate of $300 \mathrm{~nm} \mathrm{~min}-1$ and a resolution of $2 \mathrm{~nm}$. Sample temperature was kept constant at $37^{\circ} \mathrm{C}$ through a Varian Dual Cell Peltier device. Data processing was performed with Cary WINUV version 4.2 (Varian Inc.).

Circular Dichroism. CD measurements were acquired at $25^{\circ} \mathrm{C}$ with a Jasco $\mathrm{J}-715$ spectropolarimeter (scan rate: $50 \mathrm{~nm} \mathrm{~min}{ }^{-1}$ ) using Hellman quartz cells of 0.01 and $0.1 \mathrm{~cm}$ path length, respectively in the range 193-260 and 240-350 nm. Spectra (each being the average of eight subsequent accumulations) were recorded at standard sensitivity $(100 \mathrm{mdeg})$ with a data-pitch of $1 \mathrm{~nm}$ in the continuous mode and a resolution of $2 \mathrm{~nm}$. Data processing was carried out using SPECTRA MANAGER version 1.52 (Jasco Inc.), and values expressed in terms of total molar ellipticity [ $\theta]$ $\left(\operatorname{deg} \cdot \mathrm{cm}^{2} \cdot \mathrm{dmol}^{-1}\right)$.

Fluorescence Spectroscopy. Emission spectra were recorded at room temperature on a Perkin Elmer LS50B Luminescence Spectrometer in 1 $\mathrm{cm}$ quartz cuvettes. The emission of BSA was measured in the range $\Delta_{\mathrm{em}}=300-400 \mathrm{~nm}$ with an excitation wavelength of $288 \mathrm{~nm}$. The excitation and emission slits were fixed at $5 \mathrm{~nm}$, scanning speed $40 \mathrm{~nm} / \mathrm{min}(10$ accumulations). 


\section{X-Ray diffraction}

Single-crystal data were collected with either a Bruker Smart APEXII area detector diffractometer (for IT05), or an Agilent Technologies Gemini E four-circle kappa diffractometer equipped with a $92 \mathrm{~mm}$ EOS CCD detector (for IT03/IT04), or a Philips PW1100 serial diffractometer (for Z-L-Pro-Aib$\mathrm{OtBu})$, using MoK $\alpha$ radiation $(\lambda=0.71073 \AA)$ for the gold(III) complexes while CuK $\alpha(\lambda=1.54178 \AA)$ for the dipeptide. The structures were solved by direct methods (SIR2002 ${ }^{[86 a]}$ or SIR2004[86b] programs) and refined by full-matrix least-squares procedures on $\mathrm{F}^{2}$ (SHELXL-14 program $\left.{ }^{[87]}\right)$, using the WinGX software package ${ }^{[88]}$. $\mathrm{H}$-atoms were calculated at idealized positions and refined using a riding model. Graphical material was prepared with the ORTEP3 for Windows ${ }^{[89]}$ and Mercury CSD $3.1^{[90}$ programs. Details specific to the individual structures are given below.

IT05. The unit cell parameters were obtained using $60 \omega$-frames of $0.5^{\circ}$ width and scanned from three different zone of reciprocal lattice. The intensity data were integrated from several series of exposures frames $\left(0.3^{\circ}\right.$ width) covering the sphere of reciprocal space ${ }^{[86]}$. An absorption correction was applied using the program SADABS ${ }^{[86]}$ with min. and max. transmission factors of: $0.676-1.000$. The crystals were of poor quality and of small size, and this affected the overall quality of the data. For this reason, only the atoms comprising the coordination sphere were refined anisotropically, whereas the remaining atoms were refined isotropically. The hydrogen atoms were placed at their calculated positions. In the lattice, solvent molecules of crystallization (pentane) were found but could not be properly modelled during the refinement, and they were treated with the SQUEEZE program ${ }^{[74]}$. According to the residual electron density, the crystal lattice contained approximately one molecule of pentane per complex molecule.

IT03/IT04. Crystals were grown by slow evaporation from an acetone solution containing equimolar amounts of the two enantiomers. Data collection and reduction were performed with the CrysAlisPro software (Agilent Technologies). A semi-empirical absorption correction based on the multi-scan technique using spherical harmonics, implemented in SCALE3 ABSPACK scaling algorithm, was applied. The structure contains co-crystallized solvent, which was eventually modeled as one acetone molecule disordered over two sites with population parameters of 0.60 and 0.40 , respectively. Many crystallographic parameters suffer from far-fromoptimal crystal size and quality. In particular, crystal decay occurred during data collection. Frames with $\mathrm{R}$ (int) $>0.20$ were excluded from the dataset. As a consequence, data completeness is only $57 \%$. Restraints were imposed to the bond distances involving the disordered solvent atoms, as well as to the anisotropic displacement parameters of most of the atoms outside the metal coordination shell, to approach isotropic behavior.

$Z$-L-Pro-Aib-OtBu. The phenyl ring of the Z-group was constrained to the idealized geometry. The $\mathrm{C}^{\gamma}$ atom of the Pro residue shows positional disorder. It was refined on two sites, CG1 and CG1', each with a population parameter of 0.50 . Restrains were applied to the bond distances involving the disordered atoms.

A summary of data collection and structure refinement for all the compounds is reported in the Supporting Information (Tables S2-S7 and Figures S8-S12). X-ray crystallographic data have been deposited at the Cambridge Crystallographic Data Center and allocated the deposition numbers CCDC 1001852 (IT05), CCDC 1031827 (Z-L-Pro-Aib-OtBu) and CCDC 1031828 (IT03/04) and the corresponding CIF files can be obtained free of charge from http://www.ccdc.cam.ac.uk.

\section{Synthesis}

The final purity of all the synthesized compounds was $\geq 95 \%$, as determined by elemental and thermogravimetric analyses (see Supporting Information).
General synthetic route for tert-Butyl- or TEG-esterified amino acids. Z Sar-OH, Z-L/D-Pro-OH, Z-L/D-Ala-OtBu, Z-Aib-OtBu were prepared according to literature methods.

Z-Aib-OTEG. For the synthesis of Z-Aib-OTEG, 1 eq. of Z-Aib-OH (15 mmol) is dissolved in $\mathrm{CH}_{2} \mathrm{Cl}_{2}$ and cooled to $0^{\circ} \mathrm{C}$ with ice bath. To the solution are added subsequently: 1.2 eq. of HOBt; 0.3 eq. of DMAP; 1.2 equiv. di EDC; 2 eq. of TEG-OH, and the mixture is stirred for $48 \mathrm{~h}$. The solvent is evaporated at reduced pressure; the product is extracted with ethylacetate and washed with $\mathrm{KHSO}_{4}$ and $\mathrm{NaHCO}_{3}$ aqueous solutions. After removing water traces by treating with $\mathrm{Na}_{2} \mathrm{SO}_{4}$, the organic portion is dried obtaining a yellow oil which is purified by flash chromatography (eluent: petroleum ether/ethyl acetate $3: 2$ and subsequently 4.5:0.5, on silica). Yellow oil; yield: 92\%; $\mathrm{Rf}_{1}$ : $0.94 ; \mathrm{Rf}_{2}$ : $0.74 ; \mathrm{Rf}_{3}: 0.43 .{ }^{1} \mathrm{H} \mathrm{NMR}$ (300.13 MHz, DMSO-d $, 298 \mathrm{~K}, \mathrm{TMS}): 1.55$ (s, 6H, B-CH $\mathrm{Aib}) ; 3.68$ (s, $3 \mathrm{H}$ $\mathrm{O}-\mathrm{CH}_{3}$ TEG); 3.50-3.55, 3.60-3.68, 4.25-4.29 (m, 12H, - $\mathrm{CH}_{2}$ TEG); 5.08 (s , $\left.2 \mathrm{H},-\mathrm{CH}_{2} \mathrm{Z}\right) ; 5.44$ (s, $1 \mathrm{H}, \mathrm{N}-\mathrm{H}$ Aib); 7.27-7.36 (m, 5H, CH Z). FT-IR $(\mathrm{KBr}): \tilde{v}=3341$ (v, N-H); 2984/2929/2877 (v, C-H); 1739 (v, C=O ester); 1721 ( $v$, amide I); 1523 ( $v$, amide II); 1157 (v, (TEG)-O).

Synthetic route for tert-Butyl- or TEG-esterified dipeptide hydrochlorides and related intermediates. For the amino acids coupling reaction, generally, a THF solution (15-20 mL) of Z-Sar-OH is treated with NMM (22 mmol), cooled to $-15{ }^{\circ} \mathrm{C}$ and then treated with isobutyl chloroformiate $(22 \mathrm{mmol})$ under continuous stirring ${ }^{[46,47]}$. After $10 \mathrm{~min}$, a cold $\mathrm{CHCl}_{3}(10-35 \mathrm{~mL})$ suspension of $\mathrm{H}$-L/D-Ala-OtBu (or H-Aib-OtBu), H-Aib-OTEG; $22 \mathrm{mmol}$ is added, adjusting the $\mathrm{pH}$ to ca. 8 by adding NMM. After stirring overnight at room temperature, the reaction mixture is concentrated under reduced pressure and the residue is dissolved with AcOEt, washed subsequently with $10 \% \mathrm{KHSO}_{4}, \mathrm{H}_{2} \mathrm{O}, 5 \% \mathrm{NaHCO}_{3}, \mathrm{H}_{2} \mathrm{O}$, and dried over $\mathrm{Na}_{2} \mathrm{SO}_{4}$. For the Z-L/D-Pro-derivatives the coupling was achieved in $\mathrm{CH}_{2} \mathrm{Cl}_{2}$ by activating with EDC and HOBt. The organic layer is then concentrated to dryness and purified by flash chromatography using AcOEt/petroleum ether $1: 1$ as eluent, in order to obtain the corresponding Z-protected dipeptides esters (yield $=70-90 \%)$. Each Z-AA $-A_{1}-A_{2}-O R\left(A A_{1}=\right.$ Pro, Sar; $A A_{2}=$ Aib, Ala; $R$ $=\mathrm{tBu}, \mathrm{TEG}$ ) intermediate is then $\mathrm{Z}$-deprotected by catalytic hydrogenation over $\mathrm{Pd} / \mathrm{C}(20 \% \mathrm{w} / \mathrm{w})$ in $\mathrm{MeOH}$. The $\mathrm{H}-\mathrm{AA}_{1}-\mathrm{AA}_{2}-\mathrm{OR}$ compound is dissolved in dry diethylether and dropwise treated with 1 equivalent of a dilute ether solution of $\mathrm{HCl}(0.2 \mathrm{mM})$ under vigorous stirring, leading to the formation of a white precipitate corresponding to the hydrochloride form of the dipeptide, $\mathrm{HCl} \cdot \mathrm{H}-\mathrm{AA}_{1}-\mathrm{AA}_{2}-\mathrm{OR}\left(\mathrm{AA}_{1}=\mathrm{Pro}\right.$, Sar; $\mathrm{AA}_{2}=\mathrm{Aib}, \mathrm{Ala} ; \mathrm{R}=\mathrm{t}-\mathrm{Bu}$, TEG).

HCl.H-Sar-D-Ala-OtBu (P1). White powder; yield: $65 \% . \mathrm{R}_{\mathrm{f1}}: 0.13 ; \mathrm{R}_{\mathrm{t} 2}$ 0.23 ; $R_{\mathrm{f} 3}$ : 0.04 ; m.p.: $148-150^{\circ} \mathrm{C} ;[\alpha]^{20} \mathrm{D}=38.67^{\circ}(\mathrm{c}=0.5, \mathrm{MeOH}) ;{ }^{1} \mathrm{H}$ NMR (300.13 MHz, DMSO-d6, $298 \mathrm{~K}, \mathrm{TMS}$ ): $\delta=9.00$ [br, s, 2H, NH${ }^{+}$Sar]. 8.88 [d, 1H, NH Ala], 4.17 [m, 1H, a-CH Ala], 3.70 [s, 2H, N-CH2 Sar], 2.53 [s, $3 \mathrm{H}, \mathrm{N}-\mathrm{CH}_{3} \mathrm{Sar}$, 1.40 [s, $9 \mathrm{H}, \mathrm{CH}_{3} t$-Bu], $1.28 \mathrm{ppm}$ [d, $3 \mathrm{H}, \beta-\mathrm{CH}_{3}$ Ala] ${ }^{13} \mathrm{C}\left\{{ }^{1} \mathrm{H}\right\}$ NMR $(75.48 \mathrm{MHz}$, DMSO-d $6,298 \mathrm{~K}, \mathrm{TMS}): \delta=171.27$ ( $\boldsymbol{C}=\mathrm{O}$ Ala), 164.86 ( $\boldsymbol{C}=\mathrm{O}$ Sar), $80.58\left(-\boldsymbol{C}\left(\mathrm{CH}_{3}\right)_{3} t-\mathrm{Bu}\right), 48.53\left(\mathrm{~N}-\boldsymbol{C H}_{2} \mathrm{Sar}\right), 48.29$ (a- $\boldsymbol{C}$ Ala), $32.40\left(\mathrm{~N}-\boldsymbol{C H}\right.$ Sar), $27.36\left(\mathrm{CH}_{3} t-\mathrm{Bu}\right), 16.75 \mathrm{ppm}\left(\boldsymbol{\beta}-\mathrm{CH}_{3} \mathrm{Ala}\right)$; FT-IR $(\mathrm{KBr}): \tilde{v}=3332(\mathrm{v}, \mathrm{N}-\mathrm{H}) ; 2978 / 2960 / 2936(\mathrm{v}, \mathrm{C}-\mathrm{H}) ; 2763\left(\mathrm{Va}, \mathrm{NH}_{2}{ }^{+}\right) ; 2701$ $\left(\mathrm{Vs}, \mathrm{NH}_{2}{ }^{+}\right), 1735$ (v, C=O ester); 1669 (v, amide I); 1564 ( $\mathrm{v}$, amide II); 1266 (v, amide III); 1221 (v, C-O $(t-B u)) ; 1165 \mathrm{~cm}^{-1}(\mathrm{v}, t$-Bu-O).

HCl.H-Sar-L-Ala-OtBu (P2). White powder; yield: 82\%; $\mathrm{R}_{\mathrm{f1}}$ : 0.13; Rt2: 0.23 ; $\mathrm{R}_{\mathrm{f} 3}$ : 0.04 ; m.p.: $147-150^{\circ} \mathrm{C} ;[\mathrm{\alpha}]^{20} \mathrm{D}=-39.1^{\circ}(\mathrm{c}=0.5$, MeOH $) ;{ }^{1} \mathrm{H}$ NMR (300.13 MHz, DMSO-d $, 298 \mathrm{~K}, \mathrm{TMS}): \delta=9.12$ [br, s, 2H, NH Sar], 8.96

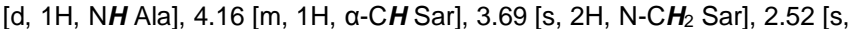
$3 \mathrm{H}, \mathrm{N}-\mathrm{CH}_{3} \mathrm{Sar}$ ], 1.40 [s, 9H, $\mathrm{CH}_{3} t$-Bu], $1.27 \mathrm{ppm}$ [d, 3H, $\beta-\mathrm{CH}_{3}$ Ala]; ${ }^{13} \mathrm{C}\left\{{ }^{1} \mathrm{H}\right\}$ NMR $(75.48 \mathrm{MHz}$, DMSO-d $6,298 \mathrm{~K}, \mathrm{TMS}): \delta=171.22$ ( $\boldsymbol{C}=\mathrm{O}$ Ala), 164.87 ( $\boldsymbol{C}=\mathrm{O}$ Sar), $80.59\left(-\boldsymbol{C}\left(\mathrm{CH}_{3}\right)_{3} t-\mathrm{Bu}\right), 48.52\left(\mathrm{~N}-\boldsymbol{C H}_{2} \mathrm{Sar}\right), 48.29$ (a- $\boldsymbol{C}$ Ala), $32.41\left(\mathrm{~N}-\mathrm{CH}_{3} \mathrm{Sar}\right), 16.76\left(\beta-\mathrm{CH}_{3} \mathrm{Ala}\right) ; 27.28 \mathrm{ppm}\left(\mathrm{CH}_{3} t\right.$-Bu); FT-IR $(\mathrm{KBr}): \tilde{v}=3332(\mathrm{v}, \mathrm{N}-\mathrm{H}) ; 2978 / 2963 / 2939(\mathrm{v}, \mathrm{C}-\mathrm{H}) ; 2766\left(\mathrm{va}_{\mathrm{a}} \mathrm{NH}_{2}{ }^{+}\right) ; 2699$ $\left(\mathrm{v}_{\mathrm{s}}, \mathrm{NH}_{2}{ }^{+}\right) ; 1735$ (v, C=O ester); 1669 (v, amide I); 1564 (v, amide II); 1266 (v, amide III); $1220(\mathrm{v}, \mathrm{C}-\mathrm{O}(t-\mathrm{Bu})) ; 1166 \mathrm{~cm}^{-1}(\mathrm{v}, t-\mathrm{Bu}-\mathrm{O})$.

HCl-H-D-Pro-Aib-OtBu (P3). White powder; yield: 49\%; $\mathrm{R}_{\mathrm{f1}}: 0.15$; $\mathrm{R}_{\mathrm{f} 2}$ : 0.30; Rf3: 0.06; m.p.: $104-108^{\circ} \mathrm{C} ;[\alpha]^{20} \mathrm{D}=-32.8^{\circ}(\mathrm{c}=0.6, \mathrm{MeOH}) ;{ }^{1} \mathrm{H}$ NMR (300.13 MHz, DMSO-d $, 298 \mathrm{~K}, \mathrm{TMS}): \delta=9.80$ [s, br, $2 \mathrm{H}, \mathrm{NH}_{2}{ }^{+}$Pro]; 8.92 
[s, $1 \mathrm{H}, \mathrm{NH}$ Aib], $4.11\left[\mathrm{~m}, 1 \mathrm{H}, \mathrm{C} \boldsymbol{P}\right.$ Pro], $3.15\left[\mathrm{~m}, 2 \mathrm{H}, \mathrm{CH}_{2}^{5} \mathrm{Pro}, 2.27\right.$ [m, $1 \mathrm{H}, \mathrm{C} \boldsymbol{H}^{\prime}$ Pro], 1.83 [m, 3H, $\mathbf{C} \boldsymbol{H}^{\beta \prime}$ Pro e $\mathrm{CH}_{2}{ }^{4}$ Pro], $1.32\left[\mathrm{~s}, 9 \mathrm{H}, \mathrm{CH}_{3} \boldsymbol{t}\right.$-Bu] $1.33,1.36 \mathrm{ppm}\left[2 \mathrm{~s}, 6 \mathrm{H}, \boldsymbol{\beta}-\mathrm{CH}_{3} \mathrm{Aib}\right] ;{ }^{13} \mathrm{C}\left\{{ }^{1} \mathrm{H}\right\}$ NMR $\left(75.48 \mathrm{MHz}, \mathrm{DMSO}-\mathrm{d}_{6}\right.$, $298 \mathrm{~K}, \mathrm{TMS}): \delta=172.15$ ( $\boldsymbol{C}=\mathrm{O}$ Aib), $167.15\left(\boldsymbol{C}=\mathrm{O}\right.$ Pro), $79.65\left(-\boldsymbol{C}\left(\mathrm{CH}_{3}\right)_{3} t\right.$ $\mathrm{Bu})$, 58.07 ( $\left.\boldsymbol{C} \mathrm{H}^{2} \mathrm{Pro}\right), 55.69\left(\mathbf{C}\left(\mathrm{CH}_{3}\right)_{2} \mathrm{Aib}\right), 45.32\left(\mathrm{CH}_{2}{ }^{5} \mathrm{Pro}\right), 29.59\left(\mathrm{CH}_{2}{ }^{3}\right.$ Pro), $27.13\left(\mathrm{CH}_{3} t-\mathrm{Bu}\right), 24.41\left(\mathrm{CH}_{3} \mathrm{Aib}\right), 23.28 \mathrm{ppm}\left(\boldsymbol{C H}_{2}{ }^{4}\right.$ Pro); FT-IR $(\mathrm{KBr}): \bar{v}=3430(\mathrm{v}, \mathrm{N}-\mathrm{H}) ; 2979 / 2935(\mathrm{v}, \mathrm{C}-\mathrm{H}) ; 2744\left(\mathrm{va}_{\mathrm{a}, \mathrm{s}}, \mathrm{NH}_{2}{ }^{+}\right) ; 1733(\mathrm{v}$, $\mathrm{C}=\mathrm{O}$ ester); $1678(\mathrm{v}$, amide I); 1551 ( $\mathrm{v}$, amide II); 1256 ( $\mathrm{v}$, amide III); 1219 $(\mathrm{v}, \mathrm{C}-\mathrm{O}(t-\mathrm{Bu})) ; 1146 \mathrm{~cm}^{-1}$ (v, $t$-Bu-O).

HCl.H-L-Pro-Aib-OtBu (P4). White powder; yield: 49\%; $\mathrm{R}_{\mathrm{ft}}$ : 0.15; $\mathrm{R}_{\mathrm{t} 2}$ : 0.30; R $\mathrm{R}_{\mathrm{f} 3}: 0.06$; m.p.: $104-108^{\circ} \mathrm{C}$. [a $]^{20} \mathrm{D}=-31.2^{\circ}(\mathrm{c}=0.7, \mathrm{MeOH}) ;{ }^{1} \mathrm{H}$ NMR

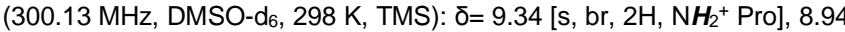
[s, $1 \mathrm{H}, \mathrm{NH}$ Aib], 4.14 [m, $1 \mathrm{H}, \mathrm{C} \boldsymbol{H}^{\text {P Pro] }}, 3.15\left[\mathrm{~m}, 2 \mathrm{H}, \mathrm{CH}_{2}{ }^{5}\right.$ Pro], $2.29[\mathrm{~m}$, $1 \mathrm{H}, \boldsymbol{C H}^{\beta \prime}$ Pro], $1.83\left[\mathrm{~m}, 3 \mathrm{H}, \mathrm{CH}^{\beta "}\right.$ and $\mathrm{CH}_{2}{ }^{4}$ Pro], $1.37 \mathrm{ppm}[2 \mathrm{~s}, 15 \mathrm{H}, \boldsymbol{\beta}-$ $\mathrm{CH}_{3}$ Aib and $\left.\mathrm{CH}_{3} t-\mathrm{Bu}\right] ;{ }^{13} \mathrm{C}\left\{{ }^{1} \mathrm{H}\right\} \mathrm{NMR}(75.48 \mathrm{MHz}$, DMSO-d $, 298 \mathrm{~K}, \mathrm{TMS})$ $\delta=172.06\left(\boldsymbol{C}=\mathrm{O}\right.$ Aib), $167.75(\boldsymbol{C}=\mathrm{O}$ Pro $), 79.65\left(\boldsymbol{C}\left(\mathrm{CH}_{3}\right)_{3} t-\mathrm{Bu}\right), 58.26\left(\mathrm{CH}^{2}\right.$ Pro), $55.70\left(\mathbf{C}\left(\mathrm{CH}_{3}\right)_{2} \mathrm{Aib}\right), 45.55\left(\mathrm{CH}_{2}{ }^{5}\right.$ Pro), $29.67\left(\mathrm{CH}_{2}{ }^{3}\right.$ Pro), $27.19\left(\mathrm{CH}_{3}\right.$ $t$ - $\mathrm{Bu}), 24.50\left(\mathrm{CH}_{3} \mathrm{Aib}\right), 23.56 \mathrm{ppm}\left(\mathrm{CH}_{2}{ }^{4} \mathrm{Pro}\right)$; $\mathrm{FT}-\mathrm{IR}(\mathrm{KBr}): \tilde{v}=3437(\mathrm{v}, \mathrm{N}-$ $\mathrm{H}) ; 2980 / 2936(\mathrm{v}, \mathrm{C}-\mathrm{H}) ; 2744\left(\mathrm{va}_{\mathrm{a}, \mathrm{s}}, \mathrm{NH}_{2}{ }^{+}\right) ; 1733(\mathrm{v}, \mathrm{C}=\mathrm{O}$ ester); $1678(\mathrm{v}$, amide I); 1551 (v, amide II); 1256 (v, amide III); 1219 (v, C-O(t-Bu)); 1146 $\mathrm{cm}^{-1}(\mathrm{v},(\mathrm{t}-\mathrm{Bu})-\mathrm{O})$.

HCI.H-Sar-Aib-OTEG (P5). Pale-yellow oil; yield: 97\%; Rf1: 0.92; Rt2: 0.69; $\mathrm{R}_{\mathrm{f} 3}: 0.33 ;{ }^{1} \mathrm{H}$ NMR $(300.13 \mathrm{MHz}$, DMSO-d 6 , $298 \mathrm{~K}, \mathrm{TMS}): \delta=9.04[\mathrm{~s}, 3 \mathrm{H}$ $\mathrm{NH}$ Aib e $\mathrm{NH}_{2}{ }^{+} \mathrm{Sar}$ ], 4.10-4.13 [m, 2H, $\mathrm{CH}_{2}{ }^{1} \mathrm{TEG}$ ], 3.66 [s, 2H, N-CH $\mathrm{H}_{2} \mathrm{Sar}$, 3.57-3.60 [m, 2H, $\mathrm{CH}_{2}^{2} \mathrm{TEG}$ ], 3.41-3.54 [m, 8H, $\mathrm{CH}_{2}{ }^{3,4,5,6} \mathrm{TEG}$ ], 3.24 [s, $3 \mathrm{H}, \mathrm{O}-\mathrm{CH}_{3} \mathrm{TEG}$ ], 2.51 [s, 3H, N-CH Sar], $1.39 \mathrm{ppm}$ [s, 6H, $\beta-\mathrm{CH}_{3} \mathrm{Aib}$ ] ${ }^{13} \mathrm{C}\left\{{ }^{1} \mathrm{H}\right\}$ NMR $(75.48 \mathrm{MHz}$, DMSO-d $6,298 \mathrm{~K}, \mathrm{TMS}): \delta=172.52$ (C=O Aib), 163.80 ( $\boldsymbol{C}=\mathrm{O}$ Sar), 68.8-70.7 ( $\left.\mathrm{CH}_{2}{ }^{3,4,5,6} \mathrm{TEG}\right), 67.44\left(\boldsymbol{C H}_{2}{ }^{2} \mathrm{TEG}\right), 63.19$ $\left(\mathrm{CH}_{2}{ }^{1} \mathrm{TEG}\right), 57.26\left(\mathrm{O}-\mathrm{CH}_{3} \mathrm{TEG}\right), 54.77\left(\mathrm{C}\left(\mathrm{CH}_{3}\right)_{2} \mathrm{Aib}\right), 47.94\left(\mathrm{~N}-\mathrm{CH}_{2} \mathrm{Sar}\right)$ $31.84\left(\mathrm{~N}-\mathrm{CH}_{3}\right.$ Sar), 23.39 ( $\left.\mathrm{\beta}-\mathrm{CH}_{3} \mathrm{Aib}\right)$; FT-IR (KBr): $\tilde{v}=3193(\mathrm{v}, \mathrm{N}-\mathrm{H})$; 2985/2937/2872 (v, C-H); $2762\left(\mathrm{~V}_{\mathrm{a}, \mathrm{s}}, \mathrm{NH}_{2}{ }^{+}\right) ; 1739$ (v, C=O ester); $1684(\mathrm{v}$ amide I); 1554 (v, amide II); 1256 (v, amide III); 1217 (v, C-OTEG); 1159 ( $v,($ TEG)-O).

General route for the synthesis of the complexes. The compound $\mathrm{HCl} \cdot \mathrm{H}$ $\mathrm{AA}_{1}-\mathrm{AA}_{2}-\mathrm{OR}\left(\mathrm{AA}_{1}=\right.$ Sar, L/D-Pro; $\left.A A_{2}=\mathrm{L} / \mathrm{D}-\mathrm{Ala}, \mathrm{Aib} ; 0.7 \mathrm{mmol}\right)$ is dissolved in water and the solution was kept at $0^{\circ} \mathrm{C}$ with a water/ice bath Under continuous stirring, cold $\mathrm{CS}_{2}(1.4 \mathrm{mmol})$ and sodium hydroxide $(0.7$ $\mathrm{mmol}$ ) are added to the solution. The variation of $\mathrm{pH}$ from 9 to 6 confirms the reaction of the dipeptide with $\mathrm{CS}_{2}$ and the consequent formation of the dithiocarbamato derivative. The ligand solution is then added, under vigorous stirring, to an ice-cold water solution of $\mathrm{K}\left[\mathrm{Au}^{\mathrm{III}} \mathrm{Br}_{4}\right](0.35 \mathrm{mmol})$, leading to the formation of a yellow ochre-brown precipitate. The solid is separated from the mother liquor and washed several times with ice-cold water, then purified by flash chromatography and dried under reduced pressure with $\mathrm{P}_{2} \mathrm{O}_{5}$.

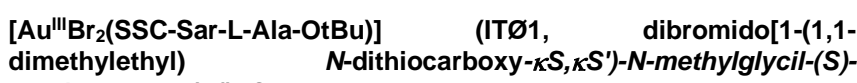
alaninato]gold(III)). Ochre powder; yield: $86 \%$;

${ }^{1} \mathrm{H}$ NMR (300.13 MHz, acetone-d6, $\left.298 \mathrm{~K}, \mathrm{TMS}\right): \delta=7.93$ (d, 1H, NH Ala), 4.71 (s, 2H, NCH $\mathrm{Nar}_{2}, 4.37$ (m, $1 \mathrm{H}, \mathrm{CH}$ Ala), 3.54 ( $\mathrm{s}, 3 \mathrm{H}, \mathrm{NCH}_{3} \mathrm{Sar}$ ), 1.45 (s, 9H, $\left.\mathrm{CH}_{3} \mathrm{tBu}\right), 1.36 \mathrm{ppm}$ (d, 3H, $\mathrm{CH}_{3}$ Ala); ${ }^{1} \mathrm{H}$ NMR $(300.13 \mathrm{MHz}$, DMSO-d, 298 K, ס/ppm, TMS): 8.79 (m, 1H, NH Ala), 4.53 (m, 2H, NCH Sar), 4.18 (m, 1H, CH Ala), 3.37 (s, 3H, $\mathrm{NCH}_{3}$ Sar), 1.40 (s, 9H, $\mathrm{CH}_{3} \mathrm{tBu}$ ), $1.23 \mathrm{ppm}\left(\mathrm{d}, 3 \mathrm{H}, \mathrm{CH}_{3} \mathrm{Ala}\right) ;{ }^{3} \mathrm{C}\left\{{ }^{1} \mathrm{H}\right\} \operatorname{NMR}(75.48 \mathrm{MHz}$, acetone-d $6,298 \mathrm{~K}$, TMS): $\delta=198.2$ (CSS), 172.54 ( $\boldsymbol{C}=\mathrm{O}$ Ala), 164.72 ( $C=\mathrm{O}$ Sar), 82.36 $\left(\boldsymbol{C}\left(\mathrm{CH}_{3}\right)_{3} t \mathrm{Bu}\right), 55.5\left(\mathrm{NCH}_{2} \mathrm{Sar}\right), 50.35$ (CH Ala), $40.5\left(\mathrm{NCH}_{3} \mathrm{Sar}\right), 28.35$ $\left(\mathrm{CH}_{3}\right.$ tBu), $18.34\left(\mathrm{CH}_{3} \mathrm{Ala}\right)$; IR $(\mathrm{KBr}): \bar{v}=3317(\mathrm{v}, \mathrm{N}-\mathrm{H}) ; 2979 / 2932$ (v, C$\mathrm{H}) ; 1733$ (v, C=O ester); 1668 (v, amide I); 1564 (n, N-CSS+amide II); 1219 (v, C-O (tBu)+amide III); $1149(\mathrm{v},(t \mathrm{Bu})-\mathrm{O}) ; 1003 \mathrm{~cm}^{-1}\left(\mathrm{va}_{\mathrm{a}}, \mathrm{S}-\mathrm{C}-\mathrm{S}\right)$. FT-IR (nujol): $\tilde{v}=567\left(\mathrm{v}_{\mathrm{s}}, \mathrm{S}-\mathrm{C}-\mathrm{S}\right) ; 419\left(\mathrm{v}_{\mathrm{a}}, \mathrm{S}-\mathrm{Au}-\mathrm{S}\right) ; 380\left(\mathrm{v}_{\mathrm{s}}, \mathrm{S}-\mathrm{Au}-\mathrm{S}\right) ; 251\left(\mathrm{v}_{\mathrm{a}}\right.$ $\mathrm{Br}-\mathrm{Au}-\mathrm{Br}) ; 229 \mathrm{~cm}^{-1}\left(\mathrm{v}_{\mathrm{s}}, \mathrm{Br}-\mathrm{Au}-\mathrm{Br}\right)$. Elemental analysis: calcd (\%) for $\mathrm{C}_{11} \mathrm{H}_{19} \mathrm{AuBr}_{2} \mathrm{~N}_{2} \mathrm{O}_{3} \mathrm{~S}_{2}\left(648.19 \mathrm{~g} \mathrm{~mol}^{-1}\right): \mathrm{C}, 20.38 ; \mathrm{H}, 2.95 ; \mathrm{N}, 4.32 ; \mathrm{S}, 9.89 \%$; found: C, 20.52; H, 2.93; N, 4.41; S, 9.90\%. TG (air): calcd weight loss to $\mathrm{Au}(0)-69.6 \%$; found $-68.0 \%$.

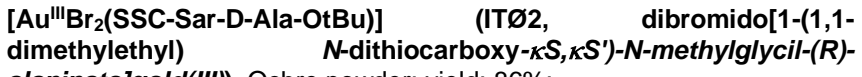
alaninato]gold(III)). Ochre powder; yield: $86 \%$;

${ }^{1} \mathrm{H}$ NMR (300.13 MHz, acetone- $\left.\mathrm{d}_{6}, 298 \mathrm{~K}, \mathrm{TMS}\right): \delta=7.94$ (d, $1 \mathrm{H}, \mathrm{NH}$ Ala), 4.69 (s, 2H, NCH $\left.H_{2} \mathrm{Sar}\right), 4.37$ (m, $1 \mathrm{H}, \mathrm{CH}$ Ala), 3.53 ( s, 3H, $\mathrm{NCH}_{3} \mathrm{Sar}$ ) 1.45 (s, 9H, CH $\left.\mathrm{CH}_{3} \mathrm{tB}\right), 1.36$ (d, 3H, $\left.\mathrm{CH}_{3} \mathrm{Ala}\right) ;{ }^{1} \mathrm{H}$ NMR $(300.13 \mathrm{MHz}$, DMSO$\left.\mathrm{d}_{6}, 298 \mathrm{~K}, \mathrm{TMS}\right): \delta=8.79(\mathrm{~m}, 1 \mathrm{H}, \mathrm{NH}$ Ala), $4.53(\mathrm{~m}, 2 \mathrm{H}, \mathrm{NCH}$ Sar), 4.17 (m, 1H, CH Ala), 3.36 (s, 3H, $\left.\mathrm{NCH}_{3} \mathrm{Sar}\right), 1.41$ (s, 9H, $\left.\mathrm{CH}_{3} \mathrm{tBu}\right), 1.28$ (d, $3 \mathrm{H}, \mathrm{CH}_{3}$ Ala); ${ }^{13} \mathrm{C}\left\{{ }^{1} \mathrm{H}\right\}$ NMR $(75.48 \mathrm{MHz}$, acetone-d6, $298 \mathrm{~K}, \mathrm{TMS})$ $\delta=197.72$ (CSS), 171.88 ( $\boldsymbol{C}=\mathrm{O}$ Ala), 163.81 ( $\boldsymbol{C}=\mathrm{O}$ Sar), $81.70\left(\boldsymbol{C}\left(\mathrm{CH}_{3}\right)_{3}\right.$ tBu), $54.83\left(\mathrm{NCH}_{2} \mathrm{Sar}\right), 49.68$ ( $\left.\mathrm{CH} \mathrm{Ala}\right), 39.9\left(\mathrm{NCH}_{3} \mathrm{Sar}\right), 27.69\left(\mathrm{CH}_{3} \mathrm{tBu}\right)$, 17.67 (CH3 Ala); FT-IR (KBr): $\bar{v}=3311(\mathrm{v}, \mathrm{N}-\mathrm{H}) ; 2979 / 2933(\mathrm{v}, \mathrm{C}-\mathrm{H}) ; 1732$ (v, C=O ester); 1668 (v, amide I); 1563 (v, N-CSS+amide II); 1218 (v, C$\mathrm{O}(t \mathrm{Bu})+$ amide III); $1149(\mathrm{v},(t \mathrm{Bu})-\mathrm{O}) ; 1003$ ( $\mathrm{va}, \mathrm{S}-\mathrm{C}-\mathrm{S}) . \mathrm{IR}$ (nujol): $\tilde{v}=566$ $\left(\mathrm{v}_{\mathrm{s}}, \mathrm{S}-\mathrm{C}-\mathrm{S}\right) ; 419$ ( $\left.\mathrm{v}_{\mathrm{a}}, \mathrm{S}-\mathrm{Au}-\mathrm{S}\right) ; 380$ ( $\left.\mathrm{v}_{\mathrm{s}}, \mathrm{S}-\mathrm{Au}-\mathrm{S}\right) ; 251$ ( $\left.\mathrm{va}, \mathrm{Br}-\mathrm{Au}-\mathrm{Br}\right) ; 228$ $\mathrm{cm}^{-1}\left(\mathrm{v}_{\mathrm{s}}, \mathrm{Br}-\mathrm{Au}-\mathrm{Br}\right)$. Elemental Analysis calcd (\%) for $\mathrm{C}_{11} \mathrm{H}_{19} \mathrm{AuBr}_{2} \mathrm{~N}_{2} \mathrm{O}_{3} \mathrm{~S}_{2}$ $\left(648.19 \mathrm{~g} \mathrm{~mol}^{-1}\right): \mathrm{C}, 20.38 ; \mathrm{H}, 2.95 ; \mathrm{N}, 4.32 ; \mathrm{S}, 9.89 \%$; found: C, 19.96; H, $2.86 ; \mathrm{N}, 4.55 ; \mathrm{S}, 9.89 \%$. TG (air): calcd weight loss to $\mathrm{Au}(0)-69.6 \%$; found $-67.9 \%$.

[Au'"'Br ${ }_{2}$ (SSC-L-Pro-Aib-OtBu)] (ITø3, dibromido[1-(1,1dimethylethyl) N-dithiocarboxy- $\left.\mathrm{KS}, \kappa S^{\prime}\right)-\mathrm{N}(\mathrm{S})$-prolyl-2methylalaninatolgold(III)). Dark-orange powder. Yield: $76 \%$.; ${ }^{1} \mathrm{H}$ NMR (300.13 MHz, acetone-d 6 , $298 \mathrm{~K}, \mathrm{TMS}$ ): $\delta=8.01$ (s, br, 1H, NH Aib), 4.92 $\mathrm{m}, 1 \mathrm{H}, \mathrm{C} \boldsymbol{H}^{\boldsymbol{P}}$ Pro), 3.98 (m, 2H, $\mathrm{CH}_{2}{ }^{5}$ Pro), $2.57 \mathrm{ùg}$ (m, $1 \mathrm{H}, \mathrm{CH}^{\beta}$ Pro), 2.32 (m, 3H, $\mathrm{CH}_{2}{ }^{4}+\mathrm{CH}_{3}{ }^{\prime}$ Pro), 1.44 (s, $\left.9 \mathrm{H}, \mathrm{CH}_{3}{ }^{\prime} \mathrm{tBu}\right), 1.45 \mathrm{ppm}\left(\mathrm{s}, 6 \mathrm{H}, \mathrm{CH}_{3}\right.$ Aib); ${ }^{1} \mathrm{H}$ NMR (300.13 MHz, DMSO-d6, $\left.298 \mathrm{~K}, \mathrm{TMS}\right): \delta=8.75$ (m, $1 \mathrm{H}, \mathrm{NH}$ Aib), $4.76\left(\mathrm{~m}, 1 \mathrm{H}, \mathrm{C} \boldsymbol{H}^{2}\right.$ Pro), $3.88\left(\mathrm{~m}, 2 \mathrm{H}, \mathrm{CH}_{2}{ }^{5}\right.$ Pro), 2.41 (m, $1 \mathrm{H}, \mathrm{CH}_{3}{ }^{\prime}$ Pro), 2.08 (m, $3 \mathrm{H}, \mathrm{CH}_{2}{ }^{4}+\mathrm{CH}^{\beta^{\prime \prime}}$ Pro), $1.38\left(\mathrm{~s}, 9 \mathrm{H}, \mathrm{CH}_{3} t-\mathrm{Bu}\right), 1.33 \mathrm{ppm}(\mathrm{s}$, $6 \mathrm{H}, \mathrm{CH}_{3}$ Aib); ${ }^{13} \mathrm{C}\left\{{ }^{1} \mathrm{H}\right\}$ NMR $(75.48 \mathrm{MHz}$, acetone-d $6,298 \mathrm{~K}$, TMS) $\delta=190.22$ (-CSS), 172.84 ( $\boldsymbol{C}=\mathrm{O}$ Aib), 166.69 ( $\boldsymbol{C}=\mathrm{O}$ Pro), $80.98\left(\boldsymbol{C}\left(\mathrm{CH}_{3}\right)_{3}\right.$ tBu), $64.87\left(\mathrm{CH}^{2}\right.$ Pro $), 57.28\left(\mathrm{C}\left(\mathrm{CH}_{3}\right)_{2} \mathrm{Aib}\right), 52.10\left(\mathrm{CH}_{2}{ }^{5} \mathrm{Pro}\right), 30.84\left(\mathrm{CH}_{2}{ }^{3}\right.$ Pro), $28.00\left(\mathrm{CH}_{3} t\right.$-Bu), 25.01 $\left(\mathrm{CH}_{3} \mathrm{Aib}\right), 23.09\left(\mathrm{CH}_{2}{ }^{4} \mathrm{Pro}\right) ; \mathrm{IR}(\mathrm{KBr}): \bar{v}$ $=3341(\mathrm{v}, \mathrm{N}-\mathrm{H}) ; 2979 / 2931$ ( $\mathrm{v}, \mathrm{C}-\mathrm{H}) ; 1730$ ( $\mathrm{v}, \mathrm{C}=\mathrm{O}$ ester); 1680 ( $\mathrm{v}$, amide I); 1553 (v, N-CSS amide II); 1247 (v, C-O(tBu)+amide III); 1147 (v, (tBu)O); $1000 \mathrm{~cm}^{-1}(\mathrm{va}, \mathrm{S}-\mathrm{C}-\mathrm{S})$. FT-IR (nujol): $\tilde{v}=535\left(\mathrm{v}_{\mathrm{s}}, \mathrm{S}-\mathrm{C}-\mathrm{S}\right) ; 410$ ( $\mathrm{va}, \mathrm{S}-$ $\mathrm{Au}-\mathrm{S}$ ); 376 (vs, S-Au-S); 252 ( $\left.\mathrm{va}_{\mathrm{a}} \mathrm{Br}-\mathrm{Au}-\mathrm{Br}\right) ; 222 \mathrm{~cm}^{-1}(\mathrm{vs}, \mathrm{Br}-\mathrm{Au}-\mathrm{Br}$ ). Elemental Analysis calcd (\%) for $\mathrm{C}_{14} \mathrm{H}_{23} \mathrm{AuBr}_{2} \mathrm{~N}_{2} \mathrm{O}_{3} \mathrm{~S}_{2}\left(688.26 \mathrm{~g} \mathrm{~mol}^{-1}\right)$ : C 24.43; H, 3.37; N, 4.07; S, 9.32\%; found: C, 24.59; H, 3.47; N, 4.14; S, $8.98 \%$. TG (air): calcd weight loss to $\mathrm{Au}(0)-71.4 \%$; found $-72.0 \%$.

\section{[Au'"'Br${ }_{2}$ (SSC-D-Pro-Aib-OtBu)] (ITø4, dibromido[1-(1,1-} dimethylethyl) $\quad N$-dithiocarboxy- $\left.k S, k S^{\prime}\right)-N(R)$-prolyl-2methylalaninato]gold(III)). Dark-orange powder; obtained as described for the synthesis of IT03. Yield: $25 \%$; ${ }^{1} \mathrm{H}$ NMR $(300.13 \mathrm{MHz}$, acetone-d6, $298 \mathrm{~K}, \mathrm{TMS}): \delta=8.00$ (s, br, $1 \mathrm{H}, \mathrm{NH}$ Aib), $4.92\left(\mathrm{~m}, 1 \mathrm{H}, \mathrm{C} \boldsymbol{H}^{2}\right.$ Pro), $3.98(\mathrm{~m}$, $2 \mathrm{H}, \mathrm{CH}_{2}{ }^{5} \mathrm{Pro}$ ), 2.58 (m, $1 \mathrm{H}, \mathrm{CH}_{3}$ Pro), 2.33 (m, $3 \mathrm{H}, \mathrm{CH}_{2}{ }^{4}+\mathrm{CH}^{3 \prime \prime}$ Pro), 1.44 (s, $9 \mathrm{H}, \mathrm{CH}_{3}$ tBu), 1.45 (s, $6 \mathrm{H}, \mathrm{CH}_{3}$ Aib); ${ }^{1} \mathrm{H}$ NMR $(300.13 \mathrm{MHz}$, DMSO-d 6 , $298 \mathrm{~K}, \mathrm{TMS}): \delta=8.78$ (s, br, $1 \mathrm{H}, \mathrm{NH}$ Aib), 4.76 ( $\mathrm{m}, 1 \mathrm{H}, \mathrm{C} \boldsymbol{H}^{2}$ Pro), 3.89 ( $\mathrm{m}$, $2 \mathrm{H}, \mathrm{CH}_{2}{ }^{5}$ Pro), 2.41 (m, $1 \mathrm{H}, \mathrm{CH}_{3}$ 'Pro), 2.10 (m, 3H, $\mathrm{CH}_{2}{ }^{4}+\mathrm{CH}^{\boldsymbol{\beta}}$ "Pro), 1.38 (s, 9H, CH $\left.\mathrm{CH}_{3} \mathrm{Bu}\right), 1.31$ (s, 6H, CH $\mathrm{CH}_{3}$ Aib). ${ }^{13} \mathrm{C}\left\{{ }^{1} \mathrm{H}\right\}$ NMR $(75.48 \mathrm{MHz}$ acetone-d $6,298 \mathrm{~K}, \mathrm{TMS}$ ): $\delta=190.21$ (-CSS), 172.96 ( $\boldsymbol{C}=\mathrm{O}$ Aib), 166.94 ( $\boldsymbol{C}=\mathrm{O}$ Pro $), 81.10\left(\boldsymbol{C}\left(\mathrm{CH}_{3}\right)_{3} \mathrm{tBu}\right), 64.92\left(\boldsymbol{C H}^{2}\right.$ Pro $), 57.44\left(\mathbf{C}\left(\mathrm{CH}_{3}\right)_{2} \mathrm{Aib}\right)$ $52.08\left(\boldsymbol{C H}_{2}{ }^{5}\right.$ Pro $), 30.80\left(\boldsymbol{C H}_{2}{ }^{3}\right.$ Pro), $27.97\left(\mathrm{CH}_{3} \mathrm{tBu}\right), 24.95 \mathrm{ppm}\left(\boldsymbol{C H}_{3} \mathrm{Aib}\right)$ $23.16\left(\mathrm{CH}_{2}{ }^{4}\right.$ Pro); IR (KBr): $\bar{v}=3363(\mathrm{v}, \mathrm{N}-\mathrm{H}) ; 2982 / 2927(\mathrm{v}, \mathrm{C}-\mathrm{H}) ; 1732(\mathrm{v}$, $\mathrm{C}=\mathrm{O}$ ester); 1680 ( $\mathrm{v}$, amide I); 1549 ( $\mathrm{v}, \mathrm{N}-\mathrm{CSS}+$ amide II); 1241 ( $\mathrm{v}, \mathrm{C}$ $\mathrm{O}(\mathrm{tBu})+$ amide III); 1147 (v, (tBu)-O); $991 \mathrm{~cm}^{-1}$ (va, S-C-S). FT-IR (nujol): $\tilde{v}$ $=533\left(\mathrm{v}_{\mathrm{s}}, \mathrm{S}-\mathrm{C}-\mathrm{S}\right) ; 410\left(\mathrm{va}_{\mathrm{a}}, \mathrm{S}-\mathrm{Au}-\mathrm{S}\right) ; 376\left(\mathrm{v}_{\mathrm{s}}, \mathrm{S}-\mathrm{Au}-\mathrm{S}\right) ; 251(\mathrm{va}, \mathrm{Br}-\mathrm{Au}-$ $\mathrm{Br})$; $222 \mathrm{~cm}^{-1}(\mathrm{Vs}, \mathrm{Br}-\mathrm{Au}-\mathrm{Br})$. Elemental analysis calcd $(\%)$ for $\mathrm{C}_{14} \mathrm{H}_{23} \mathrm{AuBr}_{2} \mathrm{~N}_{2} \mathrm{O}_{3} \mathrm{~S}_{2}\left(688.26 \mathrm{~g} \mathrm{~mol}^{-1}\right)$ : C, $24.43 ; \mathrm{H}, 3.37 ; \mathrm{N}, 4.07 ; \mathrm{S}, 9.32 \%$; found: C, 24.30; H, 3.64; N, 4.06; S, 9.02\%. TG (air): calcd weight loss to $\mathrm{Au}(0)-71.4 \%$; found $-71.9 \%$.

[Au'"'Br ${ }_{2}$ (SSC-Sar-Aib-OTEG)] (ITØ5, dibromido[1-(1,1-dimethylethyl) $N$-dithiocarboxy- $\left.\kappa S, K S^{\prime}\right)-N$-methylglycil-2-methylalaninato]gold(III)). After the general synthetic procedure previously described, the compound was further purified to eliminate the presence of hydrolyzed compound at the ester function, by dissolving the product in dichloromethane and washing it with a water solution of $\mathrm{KHCO}_{3} 5 \%$. 
Dark-brown powder, Yield: 56\%. ${ }^{1} \mathrm{H}$ NMR (300.13 MHz, acetone- $\mathrm{d}_{6}, 298$ K, TMS): $\delta=8.05$ (s, br, $1 \mathrm{H}, \mathrm{NHAib}), 4.64$ (s, 2H, NCH $\mathrm{N}_{2}$ Sar), 4.19-4.22 (m, $\left.2 \mathrm{H}, \mathrm{CH}_{2}{ }^{1} \mathrm{TEG}\right), 3.65-3.68$ ( $\mathrm{m}, 2 \mathrm{H},-\mathrm{CH}_{2}{ }^{2} \mathrm{TEG}$ ), 3.51 (s, 3H, $\mathrm{NCH}_{3} \mathrm{Sar}$ ) 3.47-3.62 (m, 8H, CH${ }_{2}^{3,4,5,6}$ TEG), 3.29 (s, 3H, OCH $H_{3}$ TEG), 1.50 ppm (s, $6 \mathrm{H}, \mathrm{CH}_{3} \mathrm{Aib}$ ); ${ }^{1} \mathrm{H}$ NMR (300.13 MHz, DMSO-d $\left., 298 \mathrm{~K}, \mathrm{TMS}\right): \delta=8.83$ (s, br, $1 \mathrm{H}, \mathrm{NHAib}), 4.47$ (s, 2H, NCH Sar), 4.10-4.11 (s, br, $2 \mathrm{H},-\mathrm{CH}_{2}{ }^{1} \mathrm{TEG}$ ) 3.62-3.65 (2H, - $\left.\mathrm{CH}_{2}^{2} \mathrm{TEG}\right), 3.36-3.58$ (m, 11H, $\mathrm{CH}_{2}^{3,4,5,6} \mathrm{TEG}, \mathrm{NCH} \mathrm{H}_{3} \mathrm{Sar}$ ), 3.24 (s, 3H, OCH $H_{3}$ TEG), 1.39 (s, 6H, CH Aib); ${ }^{13} \mathrm{C}\left\{{ }^{1} \mathrm{H}\right\} \mathrm{NMR}(75.48 \mathrm{MHz}$ acetone-d $\mathrm{d}_{6}, 298 \mathrm{~K}, \mathrm{TMS}$ ): $\delta=197.3$ (CSS), 173.63 ( $\boldsymbol{C}=\mathrm{O}$ Aib), 163.54 ( $\boldsymbol{C}=\mathrm{O}$ Sar), 70.8-71.2 ( $\left.\boldsymbol{C H}_{2}{ }^{3,4,5,6} \mathrm{TEG}\right), 69.25$ ( $\left.\mathrm{CH}_{2}{ }^{2} \mathrm{TEG}\right), 64.52\left(\mathrm{CH}_{2}{ }^{1} \mathrm{TEG}\right)$, $58.52\left(\mathrm{OCH}_{3} \mathrm{TEG}\right), 57.00\left(\mathrm{C}\left(\mathrm{CH}_{3}\right)_{2} \mathrm{Aib}\right), 54.84\left(\mathrm{NCH}_{2} \mathrm{Sar}\right), 39.86\left(\mathrm{NCH}_{3}\right.$ Sar), $24.86\left(\mathrm{CH}_{3} \mathrm{Aib}\right)$; FT-IR (KBr): $\tilde{v}=3290$ (v, N-H); 2909/2872 (v, C-H); 1735 (v, C=O ester); 1683 (v, amide I); 1576 (v, N-CSS); 1549 (v, amide II); 1253 (v, amide III); 1210 (v, C-OTEG); 1159 (v, TEG-O); $1022 \mathrm{~cm}^{-1}$ ( $\mathrm{Va}_{\mathrm{a}}, \mathrm{S}-\mathrm{C}-\mathrm{S}$ ). IR (nujol): $\bar{v}=569$ ( $\left.\mathrm{v}_{\mathrm{s}}, \mathrm{S}-\mathrm{C}-\mathrm{S}\right) ; 412$ ( $\left.\mathrm{va}, \mathrm{S}-\mathrm{Au}-\mathrm{S}\right) ; 390\left(\mathrm{v}_{\mathrm{s}}, \mathrm{S}-\mathrm{Au}\right.$ $\mathrm{S}) ; 250(\mathrm{Va}, \mathrm{Br}-\mathrm{Au}-\mathrm{Br}) ; 226 \mathrm{~cm}^{-1}(\mathrm{vs}, \mathrm{Br}-\mathrm{Au}-\mathrm{Br})$. Elemental analysis calcd (\%) for $\mathrm{C}_{15} \mathrm{H}_{27} \mathrm{AuBr}_{2} \mathrm{~N}_{2} \mathrm{O}_{6} \mathrm{~S}_{2}$ (752.30 g mol-1): C, 23.95; $\mathrm{H}, 3.62 ; \mathrm{N}, 3.72$; S, 8.52\%; found: C, 24.40; H, 3.55; N, 3.70; S, 8.57\%. TG (air): calcd weight loss to $\mathrm{Au}(0)-72.6 \%$; found $-73.8 \%$.

\section{Cell lines}

The human breast adenocarcinoma cancer cell line MCF7, the human lung cancer cell line A549 and the human ovarian cancer cell line A2780 (obtained from the European Centre of Cell Cultures ECACC, Salisbury, UK) were cultured respectively in DMEM (Dulbecco's Modified Eagle Medium) and RPMI containing GlutaMaxl supplemented with 10\% FBS and $1 \%$ penicillin/streptomycin (all from Invitrogen), at $37^{\circ} \mathrm{C}$ in a humidified atmosphere of $95 \%$ of air and $5 \% \mathrm{CO}_{2}$ (Heraeus, Germany).

Human non-small cell lung cancer cell line $\mathrm{H} 1975$ and human epidermoid carcinoma cell line A431 (obtained from the American type culture collection (ATCC)) were grown in RPMI-1640 medium (Sigma Aldrich) and in Dulbecco's modified Eagle's medium (DMEM, Sigma Aldrich) supplemented with D-glucose (final concentration $4.5 \mathrm{~g} / \mathrm{L}$, Sigma), respectively. Large cell lung carcinoma cell line $\mathrm{H} 460$ was grown in RPMI 1640 (Sigma Chemical Co.) supplemented with $2.38 \mathrm{~g} / \mathrm{L}$ Hepes, $0.11 \mathrm{~g} / \mathrm{L}$ pyruvate sodium and $2.5 \mathrm{~g} / \mathrm{L}$ glucose, $1.5 \mathrm{~g} / \mathrm{L} \mathrm{NaHCO}_{3}, 10 \%$ Heatinactivated fetal calf serum (Invitrogen), $100 \mathrm{U} / \mathrm{mL}$ penicillin, $100 \mu \mathrm{g} / \mathrm{mL}$ streptomycin, and $0.25 \mu \mathrm{g} / \mathrm{mL}$ amphotericin B (Sigma Chemical Co.) were added to the media. The cells were cultured at $37^{\circ} \mathrm{C}$ in a moist atmosphere of $5 \%$ carbon dioxide in air.

\section{In vitro cell viability assays}

For the cell lines A549, MCF7 and A2780, cells in an exponential growth rate were seeded (8,000 cells per well) in 96-well plates (Costar 3595) and grown for $24 \mathrm{~h}$ in complete medium. Solutions of the compounds were prepared by diluting a stock solution $\left(10^{-2} \mathrm{M}\right.$ in DMSO for the gold complexes, saline solution in the case of cisplatin) in culture medium (DMSO or ethanol in the culture medium never exceeded $1 \% \mathrm{v} / \mathrm{v}$ ). Subsequently, different dilutions of the compounds were added to the wells to obtain a final concentration from 0.5 to $100 \mu \mathrm{M}$.

Conversely, $\mathrm{H} 1975, \mathrm{~A} 431$ and $\mathrm{H} 460$ cells $\left(3-4 \times 10^{4}\right)$ were seeded into each well of a 24-well cell culture plate. After incubation for $24 \mathrm{~h}$, the medium was replaced with an equal volume of fresh medium, and various concentrations of the test complexes were added. The cells were then incubated in standard conditions for further 72 hours. Stock solutions of all complexes were made in dimethyl sulfoxide and then diluted with complete medium in such a way that the final amount of solvent in each well did not exceed $0.4 \% \mathrm{v} / \mathrm{v}$. Cisplatin (Sigma) was dissolved in saline solution $(0.9 \% \mathrm{w} / \mathrm{v} \mathrm{NaCl})$ up to $4 \mathrm{mM}$ and then added to each well at the indicated concentration.

Following $72 \mathrm{~h}$ of exposure, 3-(4,5-dimethylthiazol-2-yl)-2,5diphenyltetrazolium bromide (MTT) was added to the cells at a final concentration of $0.50 \mathrm{mg} / \mathrm{mL}$ in PBS (phosphate buffered saline solution, $\mathrm{pH} 7.4$ ) and incubated for $2.5 \mathrm{~h}$. The incubation medium was removed and the violet formazan crystals in the cells were dissolved in DMSO, and the optical density of each well was quantified at $550 \mathrm{~nm}$, using a multi-well plate reader (ThermoMax microplate reader, Molecular devices, US). The percentage of surviving cells was calculated from the ratio of absorbance between treated and untreated cells. Each treatment was performed in quadruplicate.
Cytotoxicity data were expressed as $\mathrm{Gl}_{50}$ values, i.e. the concentration of the test complex inducing 50\% reduction in cell number compared with control cultures.

Preparation of rat Precision-Cut Kidney Slices (PCKS) and toxicity studies ex vivo

Male Wistar rats (Charles River, France) of 250-300 g were housed under a $12 \mathrm{~h}$ dark/light cycle at constant humidity and temperature. Animals were permitted ad libitum access to tap water and standard lab chow. All experiments were approved by the Committee for care and use of laboratory animals of the University of Groningen and were performed according to strict governmental and international guidelines. Tissues were harvested (from rats anesthetized with isoflurane) and immediately placed in University of Wisconsin solution (UW, ViaSpan, $4^{\circ} \mathrm{C}$ ) until further use. PCTS were made as described by de Graaf et al. ${ }^{[25,26]}$

In brief, the intestine tissue was flushed with ice-cold Krebs-Henseleit buffer. After the removal of the muscle layer, a segment of $10 \times 20 \mathrm{~mm}$ was embedded in $3 \%$ agarose (low-gelling-temperature agarose type VII, Sigma-Aldrich, Steinheim, Germany) using a tissue embedding unit. Cores of tissue were prepared from liver and kidney using a coring tool. Specifically, after removing fat, kidneys were cut in half lengthwise using a scalpel, and cortex cores of $5 \mathrm{~mm}$ diameter were made from each half perpendicular to the cut surface using disposable Biopsy Punches (KA medical, Japan). Rat intestine, liver and kidney tissues were subsequently sliced with a Krumdieck tissue slicer (Alabama R\&D, Munford, AL, USA) in ice-cold Krebs-Henseleit buffer $\mathrm{pH} 7.4$, saturated with carbogen $(95 \%$ $\mathrm{O}_{2}$ and $5 \% \mathrm{CO}_{2}$ ). Intestinal slices (350-450 $\mu \mathrm{m}$ thick and 2-4 mg wet weight) and liver and kidney slices ( $250 \mu \mathrm{m}$ thick and $4 \mathrm{mg}$ wet weight) were stored in ice-cold Krebs-Henseleit buffer until incubation.

PCTS were incubated in 12-well plates (Greiner bio-one $\mathrm{GmbH}$ Frickenhausen, Austria) individually at $37^{\circ} \mathrm{C}$, in $1.3 \mathrm{~mL}$ Williams' medium E (WME, Gibco by Life Technologies, Paisley, UK) with glutamax-1, supplemented with $25 \mathrm{mM}$ D-glucose (Gibco) and antibiotics (liver: 50 $\mu \mathrm{g} / \mathrm{mL}$ gentamicin (Gibco); colon: $50 \mu \mathrm{g} / \mathrm{mL}$ gentamycin $+2.5 \mathrm{ug} / \mathrm{mL}$ amphotericin B; kidney: $10 \mu \mathrm{g} / \mathrm{mL}$ ciprofloxacin $\mathrm{HCl}$ ) at $\mathrm{pH} 7.4$ in an incubator (Panasonic biomedical) in an atmosphere of $80 \% \mathrm{O}_{2}$ and $5 \%$ $\mathrm{CO}_{2}$ with shaking (90 times/min).

Stock solutions of compounds IT03, AuL12 and cisplatin were prepared as for the studies on cell lines. The final concentration of DMSO during the PCTS incubation was always below $1 \% \mathrm{v} / \mathrm{v}$ to exclude solvent toxicity. For each concentration, three slices were incubated individually for one hour in WME and subsequently, different dilutions of the compounds were added to the wells, to obtain a final concentration from 0.5 to $100 \mu \mathrm{M}$. After this, kidney and liver were incubated for $24 \mathrm{~h}$. After the incubation, slices were collected for ATP and protein determination, by snap freezing them in $1 \mathrm{~mL}$ of ethanol $(70 \% \mathrm{v} / \mathrm{v})$ containing $2 \mathrm{mM}$ EDTA with $\mathrm{pH}=10.9$. After thawing, the slices were homogenized using a mini-bead beater and centrifuged. The supernatant was used for the ATP essay and the pellet was dissolved in $5 \mathrm{~N} \mathrm{NaOH}$ for the protein essay. The viability of PCTS was determined by measuring the ATP using the ATP Bioluminescence Assay kit CLS II (Roche, Mannheim, Germany) as described previously. ${ }^{[25,26]}$ The ATP content was corrected by the protein amount of each slice and expressed as pmol/ $\mathrm{\mu g}$ protein. The protein content of the PCTS was determined by the Bio-Rad DC Protein Assay (Bio-Rad, Munich, Germany) using bovine serum albumin (BSA, Sigma-Aldrich, Steinheim, Germany) for the calibration curve. The $\mathrm{TC}_{50}$ value was calculated as the toxic concentration reducing the viability of the slices by $50 \%$ with respect to the control, in terms of ATP content corrected by the protein amount of each slice and relative to the slices without any treatment (using $5 \mathrm{~h}$ vehicle control or the $24 \mathrm{~h}$ vehicle control for intestine or liver/kidney tissue, respectively), and is presented as a mean ( \pm SD) of at least three independent experiments.

\section{PARP-1 activity determinations}

PARP-1 activity was determined using Trevigen's HT Universal Colorimetric PARP Assay. This assay measures the incorporation of biotinylated poly(ADP-ribose) onto histone proteins in a 96 microtiter strip well format. Recombinant human PARP-1 (High Specific Activity, purified from E.coli containing recombinant plasmid harbouring the human PARP 
gene, supplied with the assay kit) was used as the enzyme source. 3Aminobenzamide (3-AB), provided in the kit, was used as control inhibitor. Two controls were always performed in parallel: a positive activity control for PARP-1 without inhibitors, that provided the $100 \%$ activity reference point, and a negative control, without PARP-1 to determine background absorbance. PARP-1 was incubated with different concentrations of compounds for $1 \mathrm{~h}$ or $24 \mathrm{~h}$ at RT prior deposition on the plate wells. The final reaction mixture $(50 \mu \mathrm{L})$ was treated with TACS-Sapphire ${ }^{\mathrm{TM}}$, a horseradish peroxidase colorimetric substrate, and incubated in the dark for $30 \mathrm{~min}$. Absorbance was read at $630 \mathrm{~nm}$ after $30 \mathrm{~min}$. The data correspond to means of at least three experiments performed in triplicate \pm S.D.

\section{Acknowledgements}

This work was financially supported by the University of Padova (PRAT2015 CPDA158302 and PRAT2010 CPDA109877), the Cassa di Risparmio di Padova e Rovigo Foundation (www.fondazionecariparo.it, Ph.D. studies grant for G.B.), the L'Oréal Foundation - UNESCO (http://www.forwomeninscience.com/en/fellowships, Post-doc Fellowship for C.N. within the Program "L'Oréal Italia Per le Donne e la Scienza"), T.R.N. IMBALLAGGI - logistic services (www.trnimballaggi.it/en/), the A.R.TE.M.O. Association ONLUS and the Italian Ministry of Research (PRIN 20157WW5EH). The authors gratefully acknowledge Dr. Loris Calore for elemental analyses.

Keywords: gold • metal complexes • PARP • ex vivo • cancer • serum albumin

[1] L. Kelland Nat. Rev. Cancer 2007, 7, 573-584.

[2] R. P. Miller, R. K. Tadagavadi, G. Ramesh, W. B. Reeves Toxins 2010, 2(11), 2490- 2518

[3] A. K. Holzer, S. B. Howell Cancer. Res. 2006, 66, 10944-10952.

[4] R. Safaei, A. K. Holzer, K. Katano, G. Saimi, S. B. Howell J. Inorg. Chem. 2004, 98, 1607-1613.

[5] O. Pinato, C. Musetti, C. Sissi, Metallomics, 2014, 6, 380-395.

[6] American Cancer Society, http://www.cancer.org/treatment/ (accessed 07.09.2016).

[7] K. D. Mjos, C. Orvig Chem. Rev. 2014, 114, 4540-4563.

[8] N. P. E. Barry, P. J. Sadler Chem. Comm. 2013, 49, 5106-5131.

[9] I. Ott Coord. Chem. Rev. 2009, 253(11-12), 1670-1681.

[10] M. Marloye, G. Berger, M. Gelbcke, F. Dufrasne Future Med. Chem., 2016, 8(18), 2263-2286.

[11] C. Nardon, D. Fregona Curr. Top. Med. Chem. 2016, 16(3), 360-380.

[12] C. Nardon, G. Boscutti, C. Gabbiani, L. Massai, N. Pettenuzzo, A. Fassina, L. Messori, D. Fregona, Eur. J. Inorg. Chem. 2017, 1737-1744.

[13] M. N. Kouodom, L. Ronconi, M. Celegato, C. Nardon, L. Marchiò, Q. P. Dou, D. Aldinucci, F. Formaggio, D. Fregona J. Med. Chem. 2012, 55, 2212-2226.

[14] M. N. Kouodom, G. Boscutti, M. Celegato, M. Crisma, S. Sitran, D. Aldinucci, F. Formaggio, L. Ronconi, D. Fregona J. Inorg. Biochem. 2012 117, 248-260.

[15] C. Nardon, S. M. Schmitt, H. Yang, J. Zuo, D. Fregona, Q. P. Dou PLoS One, 2014, 9(1), doi: 10.1371/journal.pone.0084248.

[16] I. Rubio-Aliaga, H. Daniel, Trends Pharmacol. Sci., 2002, 23(9), 434-440.

[17] A. Biegel, S. Gebauer, B. Hartrodt, I. Knatter, K. Neubert, M. Brandsch, I. Thondorf Eur. J. Pharm. Sci., 2007, 32(1), 69-76.

[18] H. Daniel, M. Herget, Am. J. Physiol. Renal. Physiol. 1997, 273, F1-F8.

[19] H. Daniel, E. L. Morse, S. A. Adibi, J. Biol. Chem. 1992, 267, 9565-9573.

[20] W. Kramer Biol. Chem. 2011, 392, 77-94.

[21] M. Brandsch Expert. Opin Drug. Met. 2009, 5, 887-905.
[22] M. Inoue, T. Terada, M. Okuda, K. Inui Cancer Lett 2005 230(1), 72-80.

[23] D.E. Gonzalez, K.Y. Covitz, W. Sade'e, R.J. Mrsny. Cancer Res 1998 58(3), 519-525.

[24] T. Nakanishi, I. Tamai, Y. Sai, T. Sasaki, A. Tsuji Cancer Res 1997 57(18), 4118-4122.

[25] I. A. de Graaf, P. Olinga, M. H. de Jager, M. T. Merema, R. de Kanter, E. G. van de Kerkhof, G. M. M. Groothuis, Nat. Protoc. 2010, 5, 1540-1551.

[26] I. A. de Graaf, G. M. Groothuis, P. Olinga, Expert Opin. Drug Metab. Toxicol., 2007, 3, 879-898.

[27] B. Bertrand, L. Stefan, M. Pirrotta, D. Monchaud, E. Bodio, P. Richard P. Le Gendre, E. Warmerdam, M. H. de Jager, G. M. M. Groothuis et al. Inorg. Chem. 2014, 53, 2296-2303.

[28] J. K. Muenzner, T. Rehm, B. Biersack, A. Casini, I. A. M. de Graaf, P. Worawutputtapong, A. Noor, R. Kempe, V. Brabec, J. Kasparkova et al. J. Med. Chem. 2015, 58, 6283-6292.

[29] A. Schmidt, V. Molano, M. Hollering, A. Pöthig, A. Casini, F. E. Kühn, Chem. Weinh. Bergstr. Ger. 2016, 22, 2253-2256.

[30] S. Daum, V. F. Chekhun, I. N. Todor, N. Y. Lukianova, Y. V. Shvets, L. Sellner, K. Putzker, J. Lewis, T. Zenz, I. A. M. de Graaf et al., J. Med. Chem. 2015, 58, 2015-2024.

[31] R. Rajaratnam, E. K. Martin, M. Dörr, K. Harms, A. Casini, E. Meggers, Inorg. Chem. 2015, 54, 8111-8120.

[32] A. Schmidt, V. Molano, M. Hollering, A. Pöthig, A. Casini, F. E. Kühn, Chem. Eur. J. 2016, 22, 2253-2256.

[33] P. Ramakrishnan Geethakumari, M. J. Schiewer, K. E. Knudsen, W. K. Kelly, Curr Treat Options Oncol 2017, 18(6), article number 37.

[34] A. George, S. Kaye, S. Banerjee, Nat Rev Clin Oncol., 2017, 14(5), 284 296.

[35] F. Mendes, M. Groessl, A. Nazarov, Y. O. Tsybin, G. Sava, I. Santos, P J. Dyson, A. Casini J. Med. Chem. 2011, 54, 2196-206.

[36] D. V. Ferraris J. Med. Chem. 2010, 53, 4561-4584

[37] B. Bertrand, S. Spreckelmeyer, E. Bodio, F. Cocco, M. Picquet, P. Richard, P. Le Gendre, C. Orvig, M.A. Cinellu, A. Casini Dalton Trans. 2015, 44(26), 11911-8.

[38] A. Dréan, C.J. Lord, A. Ashworth, Crit. Rev. Oncol. Hematol., 2016, 108 73-85.

[39] A. Gadducci, M. E. Guerrieri, Crit. Rev. Oncol. Hematol. 2017, 114, 153 165.

[40] K. A. Menear, C. Adcock, R. Boulter, X. Cockcroft, L. Copsey, A Cranston, K. J. Dillon, J. Drzewiecki, S. Garman, S. Gomez, H. Javaid, F. Kerrigan, C. Knights, A. Lau, V. M. Loh, I. T. W. Matthews, S. Moore, M. J. O. Connor, G. C. M. Smith, N. M. B. Martin J. Med. Chem. 2008 20, 6581-6591.

[41] F. Rojo, J. Garcia-Parra, S. Zazo, I. Tusquets, J. Ferrer-Lozano, S Menendez, P. Eroles, C. Chamizo, S. Servitja, N. Ramirez-Merino, F. Lobo, B. Bellosillo, J. M. Corominas, J. Yelamos, S. Serrano, A. Lluch, A Rovira, J. Albanell Ann. Oncol. 2012, 23, 1156-1164.

[42] L. Tentori, P. M. Lacal, A. Muzi, A. S. Dorio, C. Leonetti, M. Scarsella, F. Ruffini, W. Xu, W. Min, A. Stoppacciaro, C. Colarossi, Z. Q. Wang, J. Zhang, G. Graziani Eur. J. Cancer 2007, 43, 2124-2133.

[43] C. M. Annunziata, H. T. Stavnes, L. Kleinberg, A. Berner, L. F. Hernandez, M. J. Birrer, S. M. Steinberg, B. Davidson, E. C. Kohn Cancer 2010, 116, 3276-3284.

[44] P. O. Hassa, M. O. Hottiger Biol. Chem. 1999, 380, 953-959.

[45] F. J. Oliver, J. Menissier-de Murcia, C. Nacci, P. Decker, R. Andriantsitohaina, S. Muller, G. de la Rubia, J. C. Stoclet, G. de Murcia EMBO J. 1999, 18, 4446-4454.

[46] A. El-Faham, F. Albericio Chem. Rev. 2011, 111, 6557-6602.

[47] C. A. G. N. Montalbetti, V. Falque Tetrahedron 2005, 61, 10827-10852.

[48] F. Formaggio, Q. B. Broxterman, C. Toniolo in Houben-Weyl, Methods of Organic Chemistry, Vol. E22c Synthesis of Peptides and Peptidomimetics (Eds.: M. Goodman, A. Felix, L. Moroder, C. Toniolo), Thieme, Stuttgart, Germany, 2003, pp. 292-310.

[49] T. W. Green, P. G. M. Wuts, Protective Groups in Organic Synthesis, Wiley-Interscience, New York, 1999. 
[50] J. Chatt, L. A. Duncanson, L. M. Venanzi Suom. Kemistil. B 1956, 29B, 75-84.

[51] A. W. Herlinger, S. L. Wenhold, T. V. Long II J. Am. Chem. Soc. 1970 92, 6474-6481.

[52] L. Ronconi, L. Giovagnini, C. Marzano, F. Bettio, R. Graziani, G. Pilloni, D. Fregona Inorg. Chem. 2005, 44, 1867-1881.

[53] F. Bonati, R. Ugo J. Organomet. Chem. 1967, 10, 257-268.

[54] C. Nardon, F. Chiara, L. Brustolin, A. Gambalunga, F. Ciscato, A. Rasola, A. Trevisan, D. Fregona Chemistry Open 2015, 4, 183 - 191.

[55] F. Forghieri, C. Preti, L. Tassi, G. Tosi Polyhedron 1988, 7, 1231-1237.

[56] H. L. M. Van Gaal, J. W. Diesveld, F. W. Pijpers, J. G. M. Van Der Linden Inorg. Chem. 1979, 18, 3251-3260.

[57] G. Boscutti, L. Marchiò, L. Ronconi, D. Fregona Chem. Eur. J. 2013, 19 , 13428-13436.

[58] O. Wallach, Liebigs Ann. Chem. 1895, 286, 90-143.

[59] C.P. Brock, W.B. Schweizer, J.D. Dunitz, J. Am. Chem. Soc. 1991, 113, 9811-9820.

[60] J.M. Berg, N.W. Goffeney, Methods Enzymol.1997, 276, 619-627.

[61] T. O Yeates, S.B. Kent, Annu. Rev. Biophys. 2012, 41, 41-61.

[62] J. J. Criado, J. A. Lopez-Arias, B. Macias, L. R. Fernandez-Lago, J. M. Salas Inorg. Chim. Acta 1992, 193, 229.

[63] F. Forghieri, C. Preti, L. Tassi, G. Tosi Polyhedron, 1988, 7, 1231.

[64] A.K. Gangopadhayay, A. Chakravorty J. Chem. Phys. 1961, 35, 22062209.

[65] L. Ronconi, C. Marzano, P. Zanello, M. Corsini, G. Miolo, C. Maccà, A. Trevisan, D. Fregona J. Med. Chem. 2006, 49, 1648-1657.

[66] I. Rubio-Aliaga, H. Daniel Xenobiotica 2008, 38(7-8), 1022-1042.

[67] T. Terada, Y. Shimada, X. Pan, K. Kishimoto, T. Sakurai Biochem Pharmacol 2005 70(12), 1756-1763.

[68] K. Mitsuoka, S. Miyoshi, Y. Kato, Y. Murakami, R. Utsumi J. Nucl. Med. 2008 49(4), 615-622.

[69] E. G. van de Kerkhof, I. A. de Graaf, M. H. de Jager, D. K. Meijer, G. M. Groothuis Drug Metab. Dispos. 2005, 33, 1613-1620.

[70] A. Casini, N. Estrada-Ortiz, C. Gabbiani, F. Guarra, G. Groothuis, I. de Graaf, M. de Jager, L. Marchetti ChemMedChem. 2017, 12(17), 1429 1435.

[71] A. Meyer, L. Oehninger, Y. Geldmacher, H. Alborzinia, S. Wolfl, W.S. Sheldrick, I. Ott, ChemMedChem, 2014, 9(8), 1794-1800.

[72] U. Anand, S. Mukherjee, Biochim. Biophys. Acta 2013, 1830, 5394-5404.

[73] B. Elsadek, F. Kratz J. Control. Release 2012, 157, 4-28.

[74] K. Yamasaki, V.T. Chuang, T. Maruyama, M.Otagiri Biochim. Biophys. Acta 2013, 1830, 5435-5443.
[75] J. Anguizola, R. Matsuda, O. S. Barnaby, K.S. Hoy, C. Wa, E. Debolt, M Koke, D.S. Hage, Clin. Chim. Acta 2013, 425, 64-76.

[76] A.R. Timerbaev, C.G. Hartinger, S.S Aleksenko, B.K. Keppler, Chem Rev. 2006, 106, 2224-2248.

[77] N. Nagai, R. Okuda, M. Kinoshita, H. Ogata, J. Pharm. Pharmacol. 1996 48, 918-924.

[78] A.I. Ivanov, J. Christodoulou, J. A. Parkinson, K. J. Barnham, A. Tucker, J. Woodrow, P.J. Sadler J. Biol. Chem. 1998, 273, 14721-14730.

[79] E. M. Nagy, C. Nardon, L. Giovagnini, L. Marchiò, A. Trevisan, D. Fregona. Dalt.Trans. 2011, 40, 11885-11895.

[80] S. Shahraki, F. Shiri, M. H. Majd, Z. Razmara, J. Pharm. Biomed. Anal. 2017, 145, 273-282.

[81] S. Hamdani, D. Joly, R. Carpentier, H.A. Tajmir-Riahi J. Mol. Struct. 2009 936, 80-86.

[82] C.P. McCaul, R.D. Ludescher Photochem Photobiol 1999, 70, 166-171.

[83] G. Vignesh, S. Nehru, Y. Manojkumar, S. Arunachalam J Lumin 2014, 145, 269-277.

[84] C. Nardon, N. Pettenuzzo, D. Fregona, Curr. Med. Chem. 2016, 23 3374-3403.

[85] U.A. Laskay, C. Garino, Y.O. Tsybin, L. Salassa, A. Casini Chem. Comm. 2015, 51(9), 1612-5.

[86] a) M.C. Burla, M. Camalli, B. Carrozzini, G.L. Cascarano, C. Giacovazzo, G. Polidori, R. Spagna, J. Appl. Crystallogr. 2003, 36, 1103; b) M. C Burla, R. Caliandro, M. Camalli, B. Carrozzini, G. L. Cascarano, L. De Caro, C. Giacovazzo, G. Polidori, R. Spagna J. Appl. Crystallogr. 2005 38, 381-388.

[86] G. M. Sheldrick, Acta Crystallogr. A 2008, 64, 112-122.

[87] L. J. Farrugia J. Appl. Crystallogr. 1999, 32, 817-838.

[88] L. J. Farrugia J. Appl. Crystallogr. 2012, 45, 849-854.

[89] C. F. Macrae, I. J. Bruno, J. A. Chisholm, P. R. Edgington, P. McCabe, E. Pidcock, L. Rodriguez-Monge, R. Taylor, J. van de Streek, P. A. Wood J. Appl. Crystallogr. 2008, 41, 466-470.

[90] P. van der Sluis, A. L. Spek Acta Crystallogr. A 1990, 46, 194-201. 
